\title{
Archaeological Testing for the Mission Road Realignment Project, Phase II, at Mission Concepcion, San Antonio, Texas
}

Maureen J. Brown

Center for Archaeological Research

Anne A. Fox

Center for Archaeological Research

Barbara A. Meissner

Center for Archaeological Research

Follow this and additional works at: https://scholarworks.sfasu.edu/ita

Part of the American Material Culture Commons, Archaeological Anthropology Commons, Environmental Studies Commons, Other American Studies Commons, Other Arts and Humanities Commons, Other History of Art, Architecture, and Archaeology Commons, and the United States History Commons

Tell us how this article helped you.

This Article is brought to you for free and open access by the Center for Regional Heritage Research at SFA ScholarWorks. It has been accepted for inclusion in Index of Texas Archaeology: Open Access Gray Literature from the Lone Star State by an authorized editor of SFA ScholarWorks. For more information, please contact cdsscholarworks@sfasu.edu. 


\section{Archaeological Testing for the Mission Road Realignment Project, Phase II, at Mission Concepcion, San Antonio, Texas}

\section{Creative Commons License}

\section{(c) (1) (8)}

This work is licensed under a Creative Commons Attribution-NonCommercial 4.0 International License 


\title{
ARCHAEOLOGICAL TESTING FOR THE MISSION ROAD REALIGNMENT PROJECT, PHASE II, AT MISSION CONCEPCIÓN, SAN ANTONIO, TEXAS
}

\author{
Maureen J. Brown, Anne A. Fox, \\ and Barbara A. Meissner \\ Robert J. Hard and Jack D. Eaton, \\ Principal Investigators
}

Texas Antiquities Committee Permit No. 730

Center for Archaeological Research The University of Texas at San Antonio Archaeological Survey Report, No. 222 
The following information is provided in accordance with the General Rules of Practice and Procedure, Chapter 41.11 (Investigative Reports), Texas Antiquities Committee:

1. Type of investigation: Archaeological testing at Mission Nuestra Señora de la Purísima Concepción;

2. Project name: Mission Road Realignment, Phase II;

3. County: Bexar;

4. Principal investigators: Robert J. Hard and Jack D. Eaton; Co-principal investigator: Anne A. Fox;

5. Name and location of sponsoring agency: City of San Antonio, P.O. Box 839966, San Antonio, Texas. 78283-3966;

6. Texas Antiquities Committee Permit No.: 730;

7. Published by the Center for Archaeological Research, The University of Texas at San Antonio, San Antonio, Texas 78249-0658, 1994.

A list of publications offered by the Center for Archaeological Research can be obtained by sending $\$ 1.00$ to the Center for Archaeological Research, The University of Texas at San Antonio, 6900 N. Loop 1604 West, San Antonio, Texas 78249-0658. 


\begin{abstract}
In July 1988, the Center for Archaeological Research (CAR) contracted with the city of San Antonio to perform archaeological testing for the Mission Road Realignment Project. This project was designated as Phase II since CAR performed previous archaeological testing during February 1987 (Labadie 1989). The Mission Road Realignment Project, Phase II proposed to relocate the position of Mission Road outside the line of the original west wall of Mission Concepción. The testing sought to determine whether any structural remains or cultural deposits that may have been located outside the mission wall would be impacted by the proposed roadway.
\end{abstract}

ABSTRACT
Archaeological testing with hand-excavated units and backhoe trenches established the location of the west wall of the mission quadrangle and a portion of an interior structure wall foundation with an associated hearth and cultural midden. The northwest corner of the mission is believed to be located under the current Mission Road. Mission-period pottery, metals tools, projectile points, and animal bone were recovered from the excavations. 


\section{TABLE OF CONTENTS}

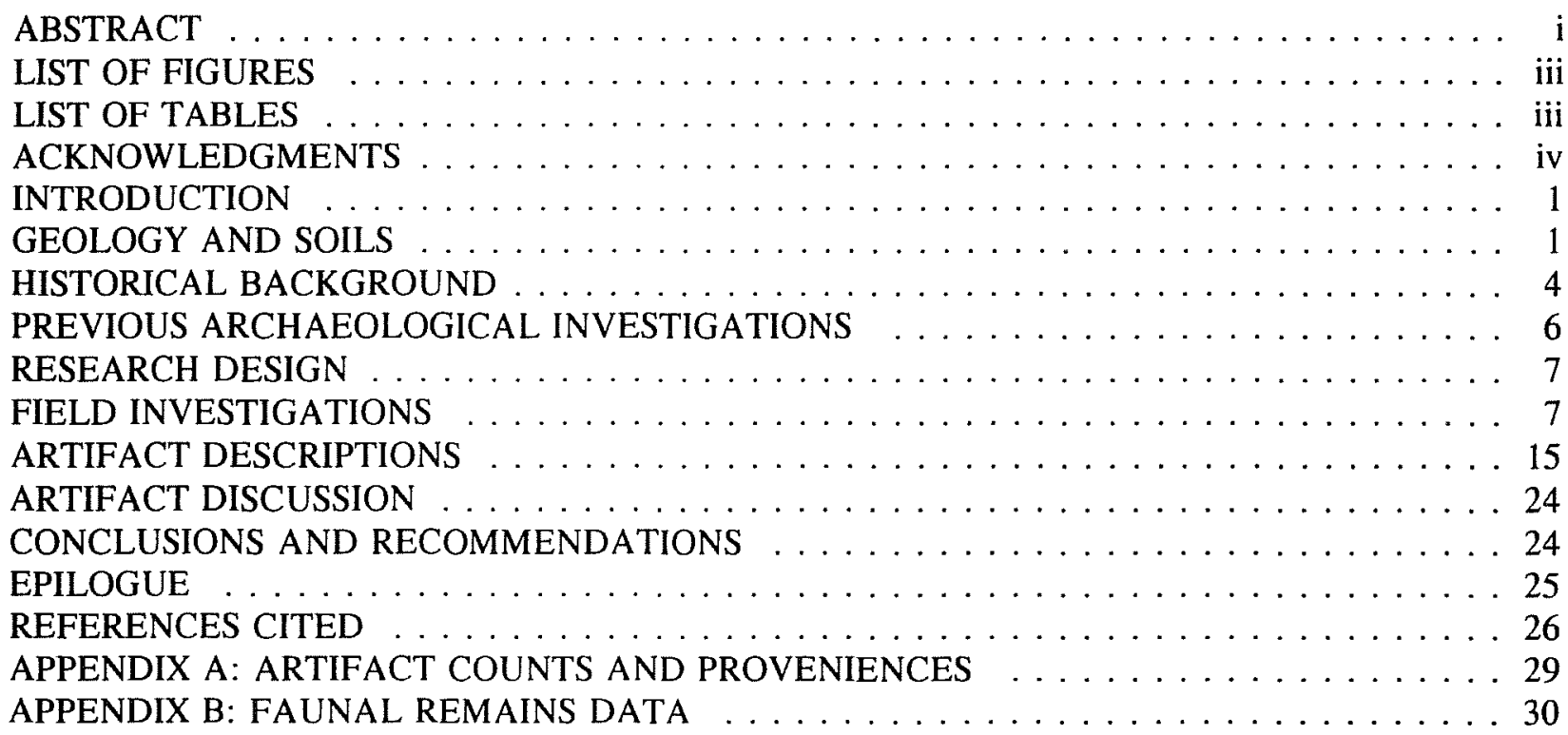




\section{LIST OF FIGURES}

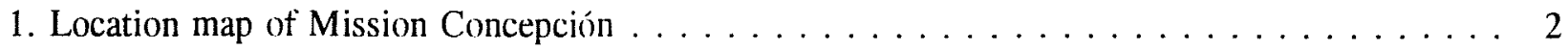

2. Mission Road Realignment Project site map . . . . . . . . . . . . . . . . . 3

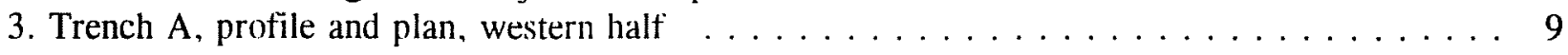

4. Trench $\mathrm{C}$, Trench $\mathrm{C}$-extension, and Trench $\mathrm{F}$, plans $\ldots \ldots \ldots \ldots \ldots$

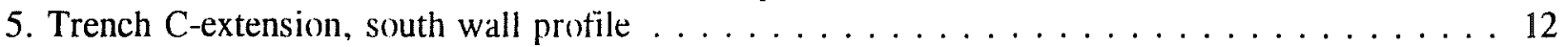

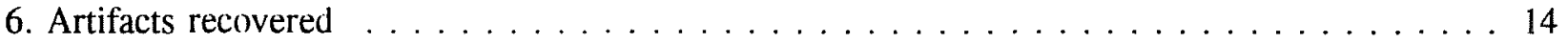

\section{LIST OF TABLES}

1. Historical Background on Mission Concepción $\ldots \ldots \ldots \ldots \ldots \ldots$

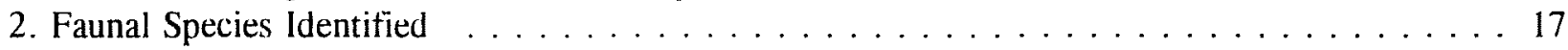

3. NISP and MNI of Identified Bones . . . . . . . . . . . . . . . . . . . 19

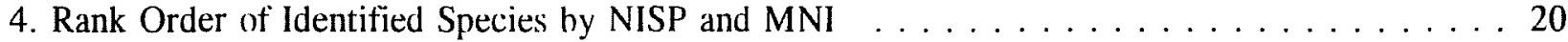

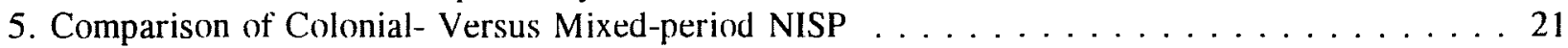

6. NISP Comparison of Mission San José and Mission Concepción Faunal Remains . . . . . . 23 


\section{ACKNOWLEDGMENTS}

I would like to thank the many dedicated individuals who worked on the Mission Road Realignment Project, Phase II, whose help made the project successful. CAR staff members for the field phase included Jack D. Eaton and Anne A. Fox as principal and co-principal investigators, and I. Waynne Cox as field director. Other CAR staff members who worked at the site included Rochelle Leneauve, who also kept the field records, processed the artifacts, and did preliminary analysis; Kenny Wright, who drew the field map; and Francis Meskill, who drew the plan maps. Volunteer crew members were Herb and Kay Allison, Ray Blackburn, Cy Bradshaw, Darla Cox, Judy Cusick, Nora De La O, David Hafernik, Curt Harrell, Joan Lloyd, Don McEwan, Clint McKenzie, Rita Neureuther, Burnley "Duke" Smith, Tommy Tomesal, and Doris Tudyk. The project could not have been accomplished without their help.
Thanks also to Mike Fulgham and John Wright of Wrightway Backhoe Service, and to the staff of the San Antonio Missions National Historical Park for their help in coordinating the project. St. Joseph's Orphanage kindly stored our equipment trailer overnight. Finally, we collectively thank all the local residents, members of the press, and people working in the area who stopped by to watch, took an interest in what we were doing, and often contributed important information to aid the project.

Robert J. Hard served as principal investigator during the final report preparation and publication stages. Marcie Renner, as technical editor, did an excellent job preparing the manuscript for publication. 


\section{INTRODUCTION}

In October 1988 an archaeological crew from the Center for Archaeological Research (CAR) of The University of Texas at San Antonio (UTSA) conducted test excavations in the southeast area of New City Block 6918. This block is located to the northwest of Mission Nuestra Señora de la Purísima Concepción de Acuña (site number 41BX12), approximately three kilometers (four miles) south of downtown San Antonio (Figure 1). Mission Concepción is part of the San Antonio Missions National Historical Park [SAMNHP]. It is also a State Archeological Landmark, is listed on the National Register of Historic Places, and has been recorded by the Historic American Buildings Survey (Fox 1988).

SAMNHP, established in 1978, is administered by the National Park Service. Mission Concepción, along with three other San Antonio missions, attracts visitors to the city. The church at Mission Concepción is the oldest of the San Antonio mission churches still standing, and continues to function as a parish church. Longrange plans for Mission Concepción are to reestablish as much as possible of the original compound wall and to reorient Mission Road to its approximate original location (Cisneros 1980).

Archaeological work was conducted under contract with the city of San Antonio. The investigation was conducted according to Section 106 of the National Historic Preservation Act of 1966 (as amended). Texas Antiquities Committee Permit No. 730 was issued for the project. Fieldwork was accomplished in 10 working days by CAR crew members, with the aid of fourteen volunteers.

The Mission Road Realignment Project, Phase II, as proposed by the city of San Antonio, was designed to follow the plan proposed by Mission Road Realignment Project, Phase I (Labadie 1989). Phases I and II were designed to relocate Mission Road and all underground utilities to the west of the alignment of the original mission west wall (Figure 2).
The original eighteenth century route of Mission Road ran outside the west wall of the mission (Ivey and Fox 1982:Figure 2). By 1890 the west wall had completely disappeared (Corner 1890) and the road was rerouted through what had been the mission compound (Bexar County Deed Records [BCDR] 54:85). In order to reconstruct the west wall, it would be necessary to move the road back to its original conformation outside the wall.

The purpose of the test excavations of Mission Road Realignment, Phase II, was first to determine if the northwest corner of the mission quadrangle lies within this area, and if so, to decide whether it would be possible to reconstruct the original mission quadrangle. Secondly, it was necessary to determine whether any other Spanish colonial structural elements or cultural deposits remain just outside or inside the west wall of the old quadrangle, and whether the new route of the road would impact any cultural remains.

\section{GEOLOGY AND SOILS}

The present site of Mission Concepción is approximately three kilometers (four miles) south of downtown San Antonio (Figure 1). During the eighteenth century, this site offered several advantages to the occupants of the mission. The San Antonio River drainage, at its closest point to the mission, was approximately one-half mile due west. Mission Concepción sits on a slightly raised knoll where at one time it would have been possible to see the entire San Antonio River valley for some distance to the north and south (Fox 1989:3).

The Soil Conservation Service has classified the immediate area of the mission as Hilly Gravelly Land (HgD), located in Venus-Frio-Trinity Association soils (Taylor et al. 1966). The soil is composed of cemented calcium carbonate sediments ("caliche") some 3-6 m thick (Taylor et al. 1966:17). Extensive travertine deposits, quarried for mission construction, are located just outside the west wall on the southwest corner of the compound (Scurlock and Fox 1977). 


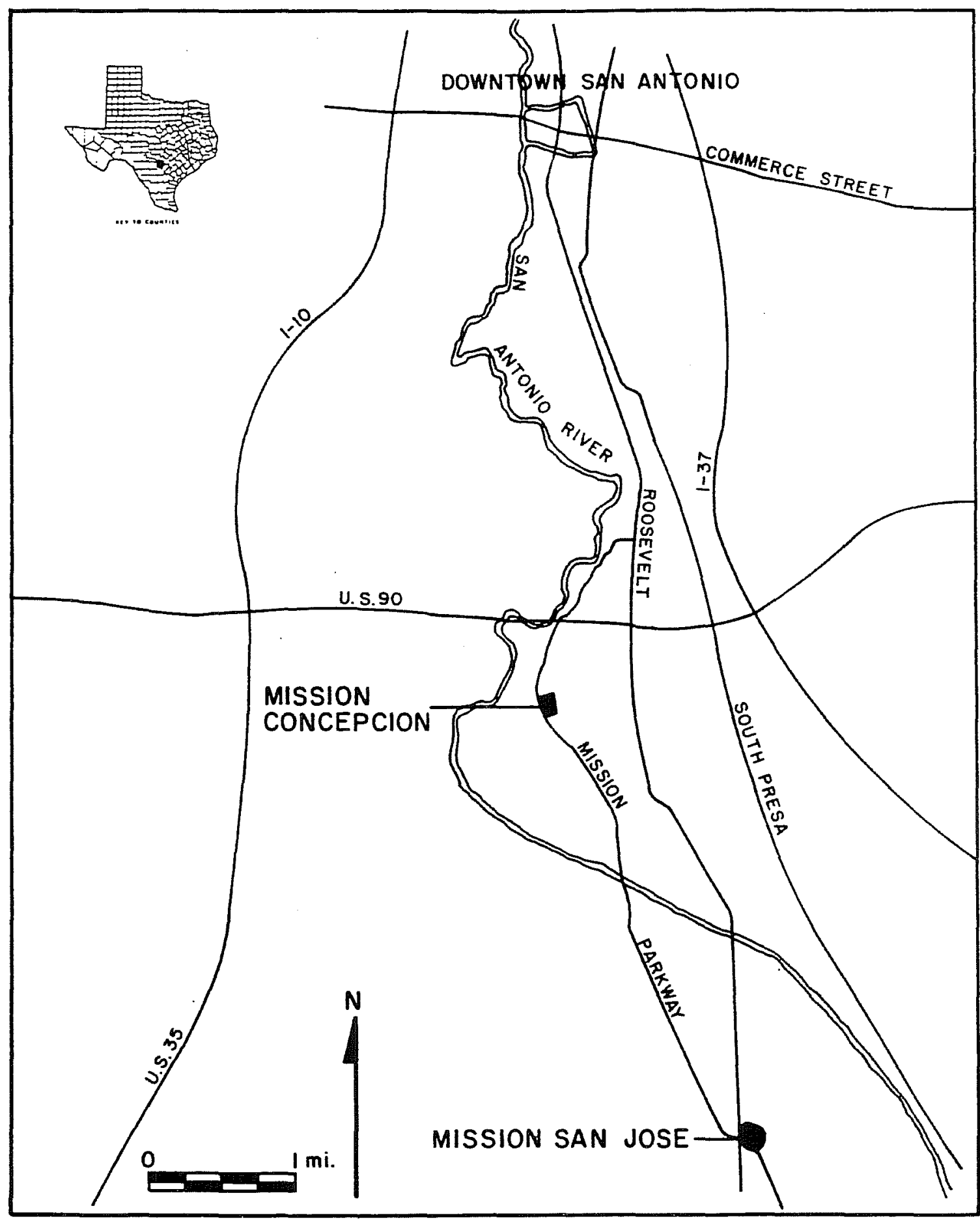

Figure 1. Location map of Mission Concepción. 


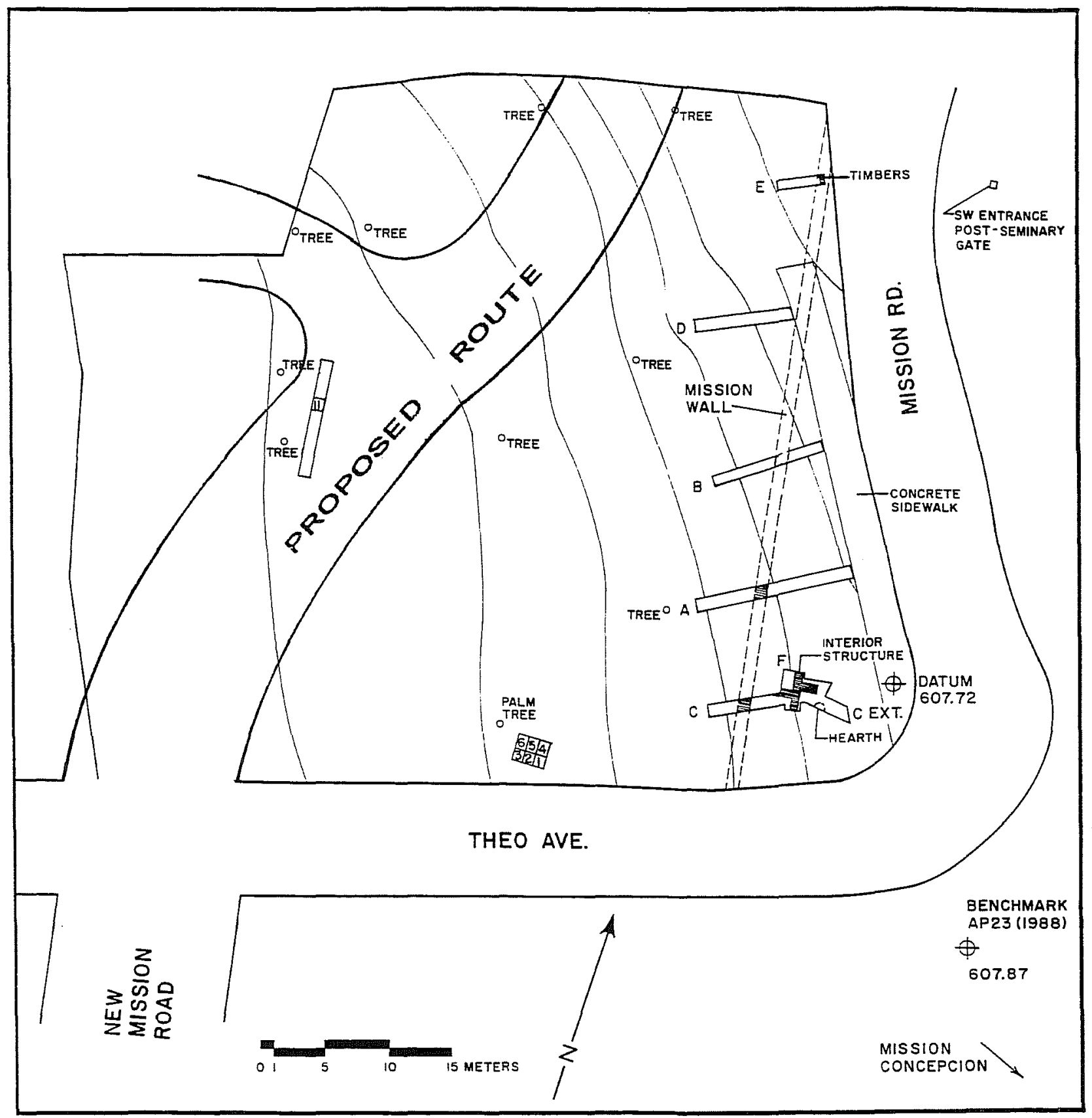

Figure 2. Mission Road Realignment Project site map. 


\section{HISTORICAL BACKGROUND}

On July 7, 1716, Franciscan missionaries founded the mission Nuestra Señora de la Purísima Concepción de los Ainais near present day Linwood Crossing in Nacogdoches County, Texas. Mission Concepción and two other missions were moved to their present locations near the San Antonio River in 1731. Approximately 300 Native Americans were brought into the new mission, including various Coahuiltecan peoples. "Coahuiltecan" is a general term given to the many different native American groups who lived in southern Texas and northern Mexico (see Campbell and Campbell 1979).

When the mission was moved to its present San Antonio location, the name became Nuestra Señora de la Purísima Concepción de Acuña (Habig 1968:125). Temporary shelters with thatched roofs, a chapel, quarters for the padres, storehouses, and huts or "jacales" for the Native Americans were constructed. In 1745 Father Ortiz reported the mission compounds were built as stone-walled fortresses, used as protection against Apache Indian raids (Habig 1968: 126-129). An uncompleted church, residences, a granary, a blacksmith shop, and a carpenter and masonry shop (Habig 1968:129) were located inside. The building material for the church and walls was limestone, quarried outside the southwest corner of the mission compound (Ivey and Thurber 1984:356-357; Labadie 1989:2).

In his 1745 inventory, Ortiz included Indian jacales of wooden poles, brush, and mud with thatched roofs (Habig 1968:128). Additional architectural details and population estimates, as reported throughout the seventeenth and eighteenth centuries, are summarized in Table 1.
Partial secularization of the mission began in 1794. At that time the lands and possessions (excepting the church) were divided among the 38 remaining Indian residents (Habig 1968: 141-142). Official final secularization of the mission occurred in 1824; before this time, the government of Mexico was already selling the surrounding lands to the local citizens (Fox 1988:5).

The property where the Phase II investigations occurred was granted to Ygnacio Chávez in 1823 (BCDR C1:218). In 1860 the land passed to Ygnacio Chávez's heirs, Juan and Antonio (BCDR S1Z:478). In 1870 Juan and Antonio Chávez sold the property to Charles and Catherine Schiebel (BCDR W2:130). Schiebel sold the property to E. L. Wickes in 1885 (BCDR 44:195), who sold it to the city of San Antonio in May 1886 (BCDR 48:583). Planning and construction for the rerouting of the original Mission Road through the center of what had once been the mission compound began ca. 1890 (Ivey and Fox 1982:53).

During the twentieth century, the property (New City Block 6918) was divided into several lots which passed through many owners. The lots located in the immediate right-of-way were lots $22,23,31 \mathrm{~A}, 31 \mathrm{~B}, 38,39,40$, and 41 . Before the area was cleared for the construction of the relocation of the road, the lots contained both residential and commercial structures. The city of San Antonio purchased the lots during the summer of 1988 . Portions of lots 22 and 23 contained a frame house and garage facing east onto the current Mission Road. A portion of lot 31 also contained a frame house and garage and faced south onto Theo Avenue. By the onset of the current phase, all that remained was a concrete sidewalk next to Mission Road, oriented north-south (Figure 2). 
Table 1. Historical Background on Mission Concepción (from Habig 1968:128-150)

\begin{tabular}{|c|c|c|c|}
\hline $\begin{array}{c}\text { Year } \\
\text { Reported }\end{array}$ & Reporter & $\begin{array}{l}\text { Population: } \\
\text { Indian/ } \\
\text { Spanish }\end{array}$ & $\begin{array}{l}\text { Mission Walls and/or } \\
\text { Indian House } \\
\text { Characteristics }\end{array}$ \\
\hline 1745 & Friar Ortiz & $207 / ?$ & $\begin{array}{l}\text { Surrounding Mission wall constructed of } \\
\text { stone and mortar. }\end{array}$ \\
\hline 1756 & Friar Ortiz & $247 / ?$ & $\begin{array}{l}\text { Walls made of stones and adobe; walls } \\
\text { are } 45 \text { inches thick. }\end{array}$ \\
\hline 1762 & $\begin{array}{l}\text { Friars Parras and } \\
\text { Ramirez de Prado }\end{array}$ & $207 / ?$ & $\begin{array}{l}\text { Walls formed rectangle for protection } \\
\text { against hostile Indians; two rows of } \\
\text { dwellings on two sides of church and } \\
\text { friary. Houses furnished with ordinary } \\
\text { household utensils. }\end{array}$ \\
\hline 1777 & Friar Morfi & $170 / ?$ & $\begin{array}{l}\text { Indian quarters consist of two parallel } \\
\text { rows on two sides (north and south walls) } \\
\text { of the compound. }\end{array}$ \\
\hline 1789 & Friar Lopez & $71 / ?$ & $\begin{array}{l}\text { Mission enclosed by a stone and mud } \\
\text { wall, with } 23 \text { rooms with flat roofs. } \\
\text { Mission wall serves as a wall for houses } \\
\text { of the same material. }\end{array}$ \\
\hline 1794 & Not given & $38 / ?$ & Mentions north and south walls. \\
\hline 1809 & Governor Salcedo & $21 / 32$ & Occupants living within compound walls. \\
\hline 1816 & Not given & $16 / 20$ & Same as above. \\
\hline 1826 & Not given & $? / 50$ & Not given. \\
\hline 1841 & George Kendall & Not given & $\begin{array}{l}\text { Walls of great thickness at all the } \\
\text { missions. }\end{array}$ \\
\hline 1890 & William Corner & Not given & $\begin{array}{l}\text { Indian houses and walls long since } \\
\text { disappeared. }\end{array}$ \\
\hline
\end{tabular}




\section{PREVIOUS ARCHAEOLOGICAL INVESTIGATIONS}

The first archaeological investigations at Mission Concepción were done in the 1930 s by Harvey P. Smith, a local architect, working with the Works Progress Administration (WPA). Smith's maps and drawings of the standing structures and many of the buried foundations, especially south of the convento, are still useful to archaeologists and others (Schuetz 1968).

In the past 20 years, several archaeological investigations have taken place on and around the grounds of the mission. Among these excavations are several which directly relate to the location of the walls surrounding the mission compound and the placement of the mission Indian quarters along the walls (Fox 1992; Ivey and Fox 1982; Labadie 1989; Scurlock and Fox 1977). Because background information on previous excavations on the church, granary, and other areas are fully described in previous CAR reports (Fox 1988, 1989; Ivey and Fox 1982; Krueger and Meskill 1992), the following is a brief summary of only those works pertinent to this investigation.

During 1971 and 1972, Dan Scurlock of the Texas Historical Commission directed investigations designed to test the moisture and structural condition of the foundations of the mission church, to test an area south of the convento, and to locate traces of the west wall of the mission (Scurlock and Fox 1977). Remains of the west wall alignment were found within two test pits, approximately $85.3 \mathrm{~m}(280 \mathrm{ft})$ west of the front of the church (Scurlock and Fox 1977:47). The sections measured $0.5 \times 2 \mathrm{~m}$ and $0.7 \times 2 \mathrm{~m}$, and were composed of large flat, irregularly shaped limestone rocks intermixed with a few colonial-period artifacts.

SAMNHP contracted with CAR to perform a series of investigations at Mission Concepción. The first, in 1980, included archaeological studies designed to relocate the original outline of the mission, to find the location of the granary, and to make an assessment of the state of preservation of the Indian quarters along the walls of the quadrangle (Ivey and Fox 1982).

Excavations revealed that the foundations of the east wall and portions of the north wall of the mission were well preserved. Living surfaces of the Indian quarters were still relatively undisturbed for much of their length. The west and south walls were present only as occasional traces in a field scraped by a bulldozer years before. By sighting along the wall alignments found by Scurlock in 1971-1972 and CAR in 1980 , it was possible to determine that the new road alignment would be well outside the line of the west compound wall.

Archival research by Ivey further delineated the original line of Mission Road. The Ivey and Fox investigations included a survey of the area of the current project. The authors called the area "C-2" or "the area north of Theo Avenue," and described it as

completely built over with twentieth-century homes, commercial establishments, driveways and cultivated yards. Ninety-nine percent of this area lies outside the west wall of the mission, and the Mission Road ran through one corner of it. With the possible exception of the alignment of the commercial building on the corner of Mission Road and Theo Avenue, no suggestion of the original mission outline remains in this area, and no mission-related artifacts are visible on the surface (Ivey and Fox 1982:129).

CAR began work on the first phase of the Mission Road Realignment Project, under the direction of Joe Labadie, in February 1987. This phase concentrated on the area of initial impact within the proposed right-of-way to the south of Theo Avenue in the western portion of the old quadrangle of Mission Concepción (Labadie 
1989:1). Previous research by Scurlock and Fox (1977) had shown that the original rock quarry and at least one acequia and portions of the western wall in the immediate area had been disturbed. The disturbance resulted from multiple bulldozer scrapings during the 1950s and 1960s when a priest from St. Joseph's Orphanage constructed and maintained a children's playground (Labadie 1989:1-2).

Labadie concentrated on locating up to three possible acequias and testing the right-of-way area for any undisturbed mission remains. Four backhoe trenches and 11 hand-excavated test units confirmed that the immediate area was indeed disturbed and filled in by the bulldozer. No evidence for the presence of in situ prehistoric or early historic occupation debris or structural remnants was found during the first phase of the Mission Road Realignment Project (Labadie 1989:13). The primary concern of Phase II is to ensure the west wall and associated material will not be impacted by construction.

\section{RESEARCH DESIGN}

Previous investigations conducted by CAR under Ivey and Fox during 1981 and 1982 (Ivey and Fox 1982) involved excavating portions of the west wall just south of Theo Avenue. Based on their data, the following four specific research questions for this phase were raised:

1) Do the remains of the west wall of the mission quadrangle extend north of the TheoMission Road intersection?

2) If they do, how much of the wall is intact, and what is its condition?

3) Where is the northwest corner of the mission compound wall, and are its remains located in the proposed area of excavation, or is it buried under the current Mission Road as proposed by Ivey and Fox?

4) What other structural and/or cultural remains exist just inside or outside the wall, and will any of these be impacted by the relocation of Mission Road?

\section{FIELD INVESTIGATIONS}

The CAR field investigations concentrated on the northwest corner area of the mission quadrangle. At the time, this area was located just north and west of the intersection of Theo Avenue and Mission Road within New City Block 6918.

All field methods employed during this project conform to the Council of Texas Archeologists standards for field investigations (CTA 1981) and to standard archaeological methods. Measurements were made in the metric system. Eleven test units were excavated, consisting of four hand-excavated, 1-x-1-m units and seven backhoe trenches. A site plan map was prepared for the entire excavation area (Figure 2) using a plane table, alidade, and stadia rod. The National Park Service benchmark AP23 (1988), elevation $607.87 \mathrm{ft}$, was utilized for the primary site datum. A closer secondary datum was placed at the corner of the sidewalk for easier mapping purposes. Floor plan maps and trench wall profiles were drawn. Black-and-white prints and color slides were taken throughout the project to document the progress and extent of the testing. All collections were processed, catalogued, and curated at the CAR laboratory. CAR is the repository for all of the collections, original field notes, maps, and photographs for this project. 


\section{BACKHOE TRENCHES}

Backhoe trenches were excavated to locate and trace the buried west wall, associated structures, and cultural remains. Once located, such remains were carefully excavated by hand. The trenches were arbitrarily labeled in the order in which they were excavated. Soil was screened through a $1 / 4$-inch wire mesh screen, recovered artifacts were bagged and brought to the laboratory for cleaning and analysis. Profile drawings and plan maps were drawn for each trench. Soil samples were collected for analysis. All excavations were then backfilled by machine.

\section{Trench A}

Trench A sought to determine if the westernmost wall of the mission compound extended to or transected the proposed right-of-way for the new road. Starting from the concrete sidewalk and moving westward, Trench A (Figure 3) was excavated to a maximum depth of $1 \mathrm{~m}$ and measured approximately $12 \mathrm{~m}$ long by $1 \mathrm{~m}$ wide. The top part of the west mission wall foundation was uncovered at a maximum depth of $0.6 \mathrm{~m}$ and was found to be oriented in a north-south direction. This section of the west wall foundation was composed of travertine rock mixed with soil. It measured approximately 1.3 $\mathrm{m}$ (1.5 varas) wide. The wall was discovered approximately $6 \mathrm{~m}$ from the west edge of the sidewalk at about $0.5 \mathrm{~m}$ below the surface. No other cultural features were found in Trench A. Three stratigraphically discrete zones were identified in this trench: a zone of grayish brown clay (10 YR 5/2), one of white caliche (10 YR $8 / 1)$, and a zone of dark gray brown clay (10 YR 4/1) (Figure 3a).

\section{Trench $B$}

Trench B dimensions were approximately $8 \mathrm{~m}$ long by $1 \mathrm{~m}$ wide by $0.9 \mathrm{~m}$ deep. This trench was designed to pick up a portion of the mission wall. Instead, a twentieth-century yellow brick wall faced with stucco was uncovered in the location where the mission wall should have been. No artifacts were recovered. The construction of this modern foundation may have displaced the original wall foundation.

\section{Trench $C$}

The placement of Trench $\mathrm{C}$ was also designed to cross the buried mission wall foundation. The trench ran approximately $6.2 \mathrm{~m}$ long by $1 \mathrm{~m}$ wide by $1 \mathrm{~m}$ deep. Two mission-period walls were uncovered approximately $3 \mathrm{~m}$ apart (Figure 4). The loose dark soil between the walls was screened for artifacts, which included a Spanish colonial knife blade, mission-period Indian pottery sherds, animal bone fragments, and a decorated porcelain sherd (see Artifact Description section).

\section{Trench $F$}

Trench $F$ was placed in the north wall of Trench $C$ at its northeast end to follow out the easternmost north-south wall found in Trench $C$ (Figure 4). A wall corner was found immediately and careful cleaning of the north wall of Trench $\mathrm{C}$ disclosed the southern edge of an east-west wall connecting the two walls in this trench. The backhoe uncovered, and subsequent careful hand excavation confirmed, a posthole just north of the wall. The bottom of the posthole was $0.7 \mathrm{~m}$ below the modern ground surface.

The area directly north and east of the wall corner was taken down to a level below the wall foundation. Small amounts of bone fragments and Indian pottery were recovered. An extension off the wall corner toward the north appeared to terminate within a short distance of the corner, and could be a buttress or wall fall. Further backhoe excavation toward the south in this trench showed that the eastern or inner wall of the structure continued toward the south, parallel to the mission west wall remnants already discovered in the test trenches. 


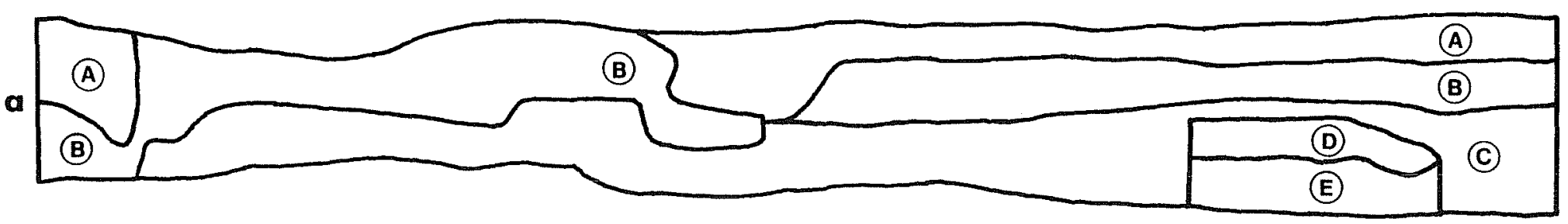

(A) GRAYISH BROWN CLAY LOAM 10 YR $5 / 2$

(B) WHITE CALICHE WITH GRAVELS 10 YR $8 / 1$

(C) DARK GRAY BROWN CLAY 10 YR $4 / 1$

(D) STONES

(E) FOOTING RUBBLE
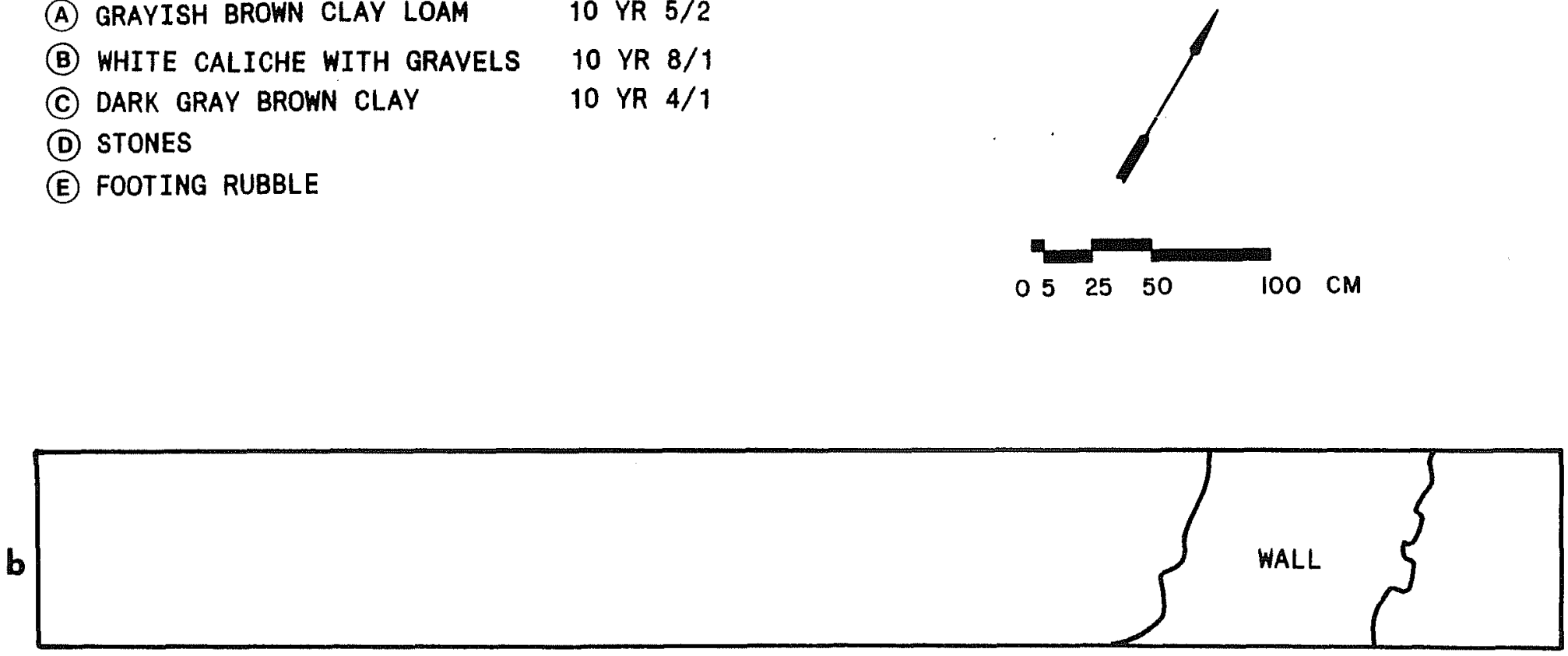

Figure 3. Trench A, profile and plan, western half. a, north wall profile; b, plan view. 


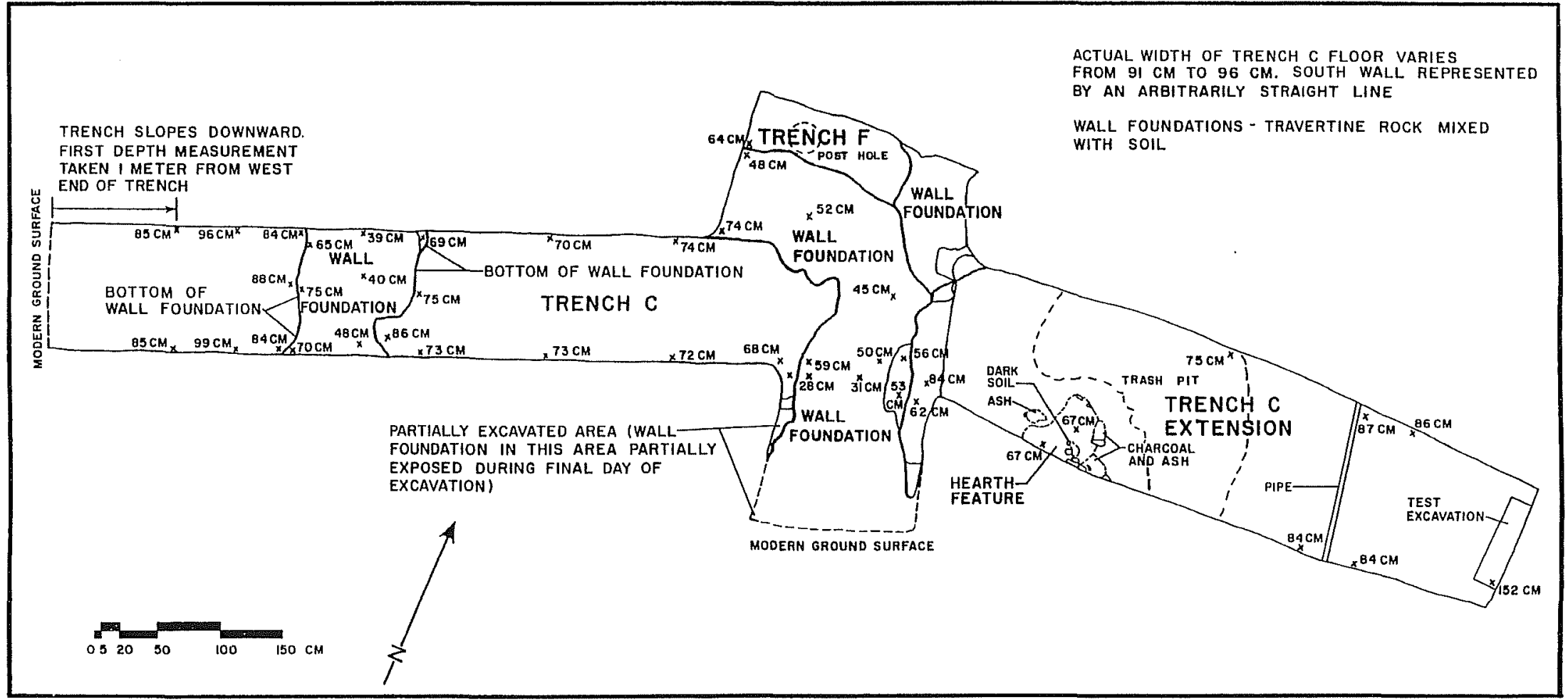

Figure 4. Trench $C$, Trench $C$-extension, and Trench $F$, plans. 


\section{Trench C-Extension}

The discovery of the northeast corner of a room built against the west wall instigated an expansion of Trench $C$ to the east to test the area immediately outside or to the east of this structure (Figure 4). If this building followed the customary plan, which was observed at this mission in 1982 (Ivey and Fox 1982), at Mission San José, and at Mission San Antonio de Valero (the Alamo), the Indian house would have been one room deep. The area immediately outside the door of the Indian dwelling would have been used for many housekeeping activities which should leave hearths, trash pits, and other archaeological evidence.

The excavations of Trenches $\mathrm{C}$ and $\mathrm{F}$ revealed cultural remains dating to the eighteenth century between the east and west walls of what appeared to be a structure similar to an Indian dwelling. The Trench $\mathrm{C}$ extension was then excavated by hand, leaving the artifacts in situ wherever possible in order to recognize and map distinct features expected to lie in this area. The final dimensions of this trench were $1.38 \mathrm{~m}$ north-south by $4.87 \mathrm{~m}$ east-west. The trench was excavated to culturally sterile soil at a maximum depth below ground surface of $0.75 \mathrm{~m}$ at the western end and $1.52 \mathrm{~m}$ at the eastern end (Figure 5). Several features were found, including a hearth and a trash accumulation.

The hearth feature was first discovered at a depth of $0.6 \mathrm{~m}$ along the south wall in Trench C-extension (Figure 4). A semicircular pattern of large and small stones was encountered against the south wall of the excavation approximately $0.7 \mathrm{~m}$ from the east wall of the structure. Beneath a shallow dark brown matrix (7.5 YR 5/6) was a reddish-brown soil (7.5 YR 4/2). Two large stones and some smaller ones were exposed at the northern perimeter of the hearth. Ashy gray soil was found on the exterior of the reddish-brown soil. Ash and a fragment of charred wood were uncovered at the northern edge of the feature. The feature was photographed, then cross-sectioned. Soil from the northern half of the hearth was screened for cultural material. Artifacts from within the hearth included burned Indian pottery, burned bone, charcoal, small fragments of metal, and a few brick/tile fragments. A profile of the hearth was drawn and soil samples were collected.

Surrounding the hearth was an area strewn with mission-period trash. Animal bone, charcoal, a metal button with drilled shank typical of the colonial period, fragments of silver braid, and sherds of various types of Spanish and Indian ceramics were first discovered at a depth of 0.36 $\mathrm{m}$ below the surface. The area was carefully excavated, with the artifacts left in situ, then plotted on a sketch map.

Directly east of this recorded feature, a 1-x-0.5$m$ unit was excavated deeper to determine the depth of the midden material. However, it was found to have been disturbed by an iron pipe the trench for which may have been dug by hand, since no trench was visible in the walls of our excavation. Mission-period artifacts continued down to the top of the pipe at $0.8 \mathrm{~m}$. Another location farther east in Trench C-extension was then excavated, resulting in the recovery of numerous artifacts. The pottery included Indian ware, lead-glazed wares, majolica, and Chinese porcelain. The soil became sterile at about $1 \mathrm{~m}$.

Apparently this trash disposal feature, including the area to the east, was the remains of a cultural midden where food processing, cooking, and discard activities took place. The location would have been inside the mission compound and just outside the door of the dwelling built against the west wall.

\section{Trench D}

Trench D was placed to test the area to the north for further evidence of the west wall of the mission compound (Figure 2). The trench dimensions were $6 \mathrm{~m}$ long by $1 \mathrm{~m}$ wide by $1 \mathrm{~m}$ deep. No evidence of wall foundations or cultural materials was found. Projecting the line of the west wall through this area suggested that 


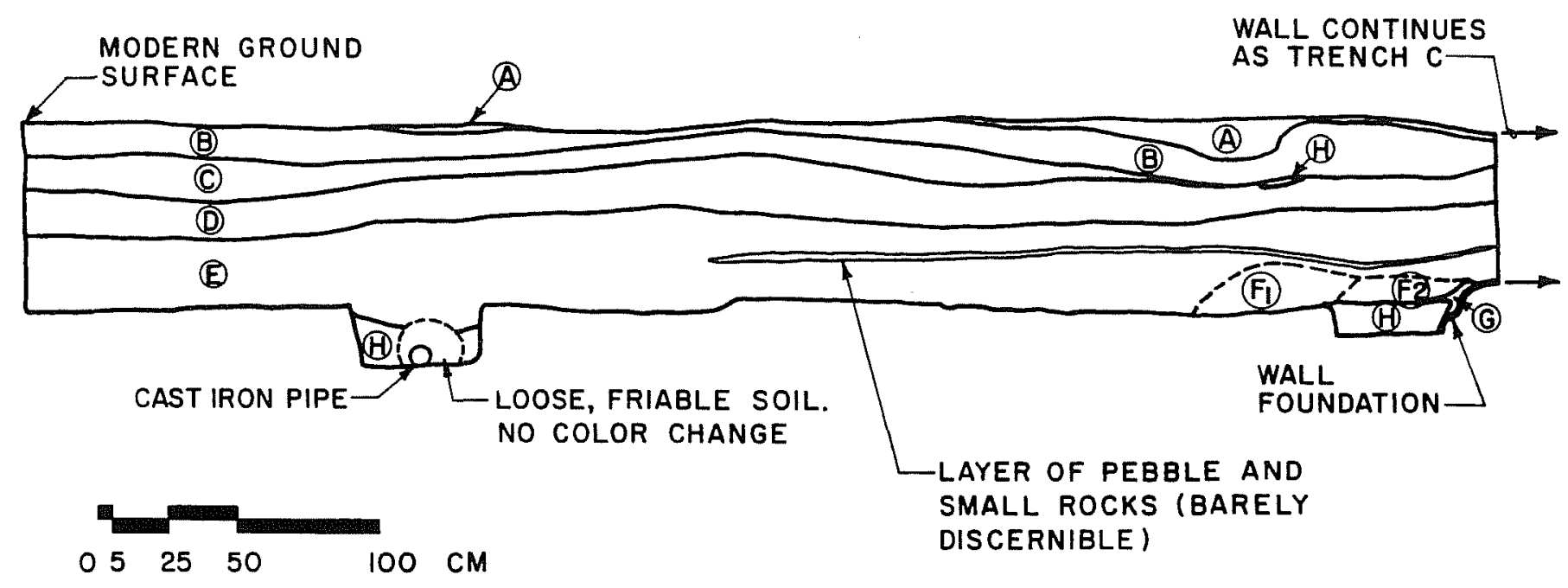

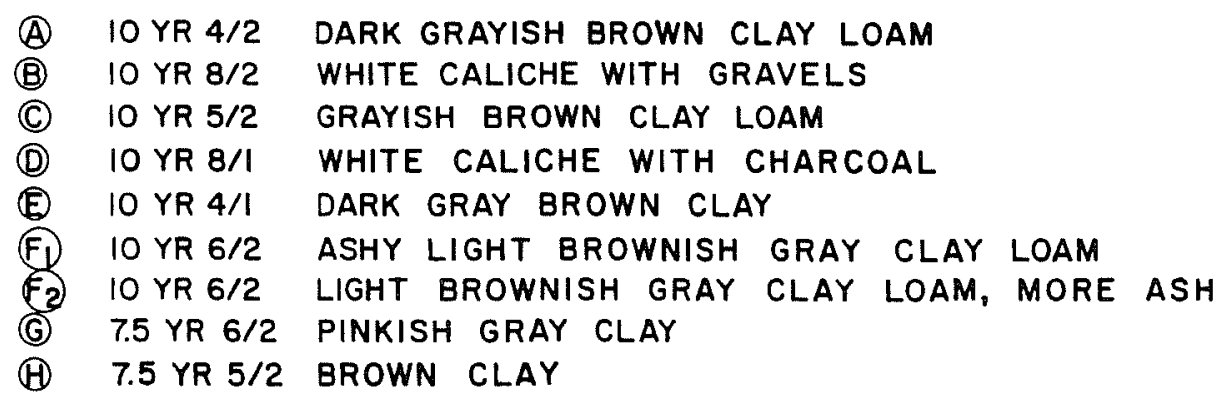

Figure 5. Trench C-extension, south wall profile. 
the foundation for the west wall probably lay just under the west edge of the sidewalk here.

\section{Trench E}

Trench E was excavated to the north, still following the line of the west wall (Figure 2). It measured $7.5 \mathrm{~m}$ long and $1 \mathrm{~m}$ wide. Adjacent to the eastern end of the trench, two squared timbers were discovered at the bottom of the trench, oriented north northwest-south southeast. The timbers were apparently treated with a preservative. The soil around the timbers was a loosely packed light brown, while the soil directly beneath the timbers was a dark brown, compact clay (10 YR 4/1). Here, again, the area where the west wall foundation should have been was disturbed by later construction.

\section{HAND-EXCAVATED UNITS}

Four $1-\mathrm{m}^{2}$ units were hand-excavated in two different areas (Figure 2). These were designed to test for cultural materials outside the west wall. The area where the first group was to be located was scraped by the backhoe to remove approximately $6 \mathrm{~cm}$ of disturbed soil. The surface at that point appeared to be an old road bed, probably the route of the original Mission Road in the eighteenth and nineteenth centuries. A grid of six units was laid out in this area and units 1,3 , and 5 were excavated. A second set of units was laid out to the northwest in the route of the new Mission Road; one of these units was chosen for excavation. Vertical control was maintained using $10 \mathrm{~cm}$ levels unless a distinct change in matrix was noted. All units were excavated to sterile soil.

\section{Unit 1}

Unit 1 was excavated in two levels. Level 1 $(0-10 \mathrm{~cm})$ contained little in the way of cultural material. Some amber beer bottle glass, animal bone, and a brick fragment were recovered. Level $2(10-26 \mathrm{~cm})$ contained a mixture of modern debris and eighteenth century remains such as Indian pottery, majolica, burned animal bone, and chert fragments. The soil was a gray clay material mixed with small fragments of limestone.

\section{Unit 3}

Unit 3 was excavated in two levels. Within Level $1(0-10 \mathrm{~cm})$ a small concentration of reddish-brown soil was found. The rest of the soil was very hard, compact gray clay. Level 2 $(10-39 \mathrm{~cm})$ contained Indian-made sherds, chert fragments, undecorated whiteware, glass, tin-can scraps, a 1981 penny, and wire nails. These materials were mixed together with no clear stratification.

\section{Unit 5}

A fragment of Huejotzingo eighteenth-century majolica (Figure 6g) was found on the surface adjacent to this unit. This unit was excavated in three distinct levels. Level $1(0-10 \mathrm{~cm})$ contained limestone and rubble concentration in the south wall of the unit. Artifacts from Level 1 included a porcelain fragment and two animal bone fragments. A Mission or Guerrero projectile point (Figure 6c) was found in Level $2(10-15 \mathrm{~cm})$. A concentration of limestone rock in the southeastern corner of the unit was associated with the point. The soil in the vicinity of the limestone was a compact reddish- brown clay. Other artifacts from Level 2 included several large animal bones and numerous bone fragments, 24 chert fragments, glass, metal and tin can scraps, several sherds of mission-period pottery, and two sherds of twentieth-century earthenware. Pieces of modern concrete pipe were also present. Although this area appears to 


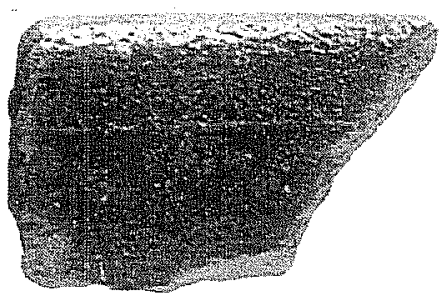

a
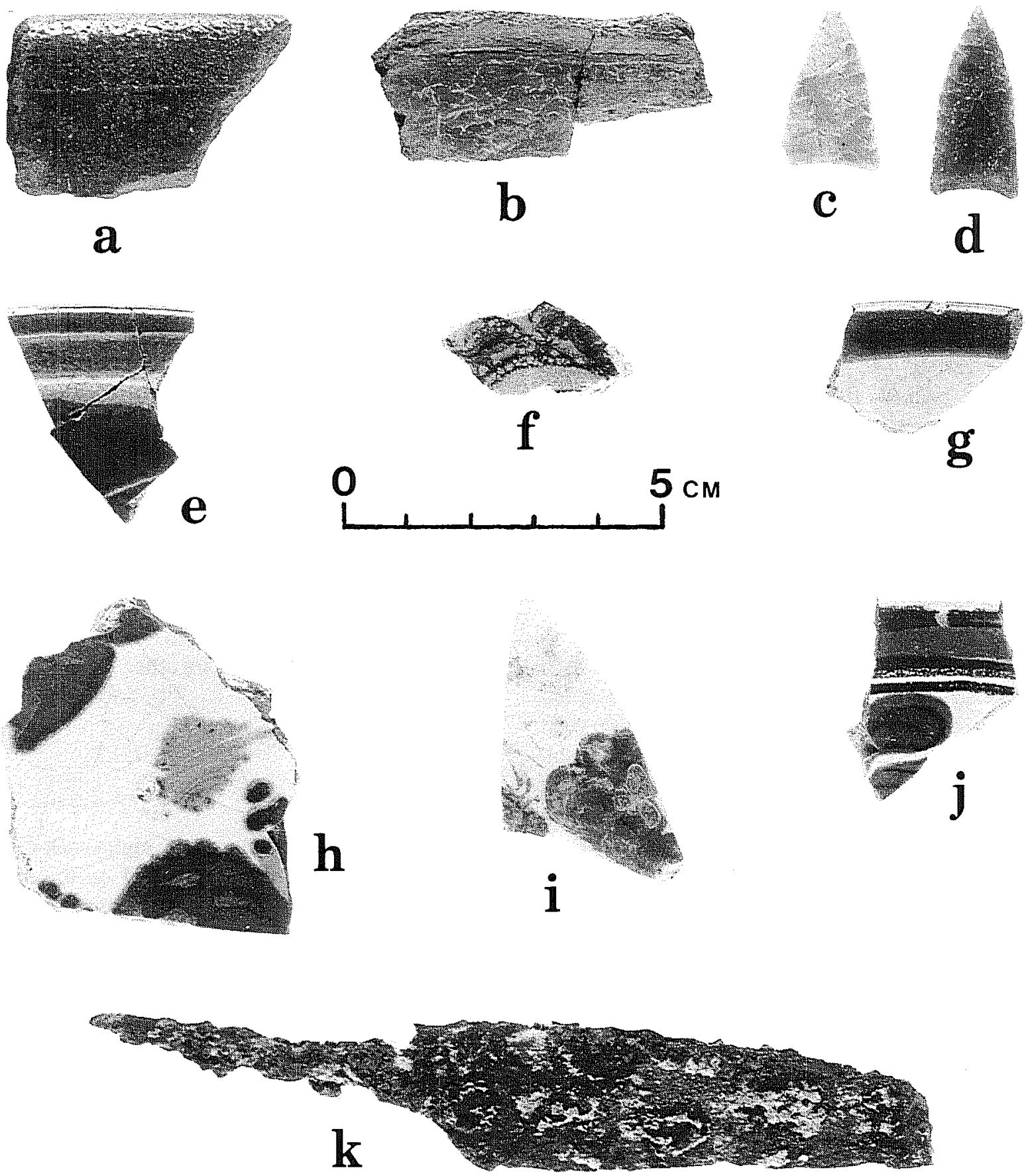

Figure 6. Recovered artifacts. a, lead-glazed Mexican ware (Trench C-extension); b, Goliad ware (Trench C-extension); c, d, Mission or Guerro points (Unit 5, Level 2, and Trench C-extension); e, San Augustine Blue-on-white majolica (Unit 5, Level 2); f, Tumacacori majolica (Trench C-extension); g, Huejotzingo majolica (Unit 5, surface); h, San Antonio Blue-on-white (Trench C-extension); i, Chinese porcelain; j, San Elizario majolica (Trench F); k, Spanish knife (Trench C). 
have been disturbed by later occupants, it may have been a trash dumping area in mission times.

\section{Unit 11}

Unit 11, located within the proposed road relocation (Figure 2), was excavated in two levels. Level $1(0-4 \mathrm{~cm})$ was a yellow gravel fill layer with fragments of animal bone and no other artifacts. Level $2(4-25 \mathrm{~cm})$ had a matrix of dark brown soil in which were found a green glass marble made between 1910 and 1935 (José Zapata, personal communication 1993), animal bone, glass fragments, wire nails and staples, one heavy whiteware sherd, and one handpainted, over-glaze sherd. All the artifacts appear to be associated with houses found in the area from the 1920s until recent times.

Results of the Hand-excavated Units

Hand-excavated units 1, 3, and 5 were in an area utilized as a dumping area from the mission period to recent times. Unit 11 contained early twentieth century to modern debris from the local residences in the immediate ared.

\section{ARTIFACT DESCRIPTIONS}

Descriptions of the various types of artifacts recovered during this project have been described in great detail in previously published excavation reports (see Ivey and $F(x)$ 1982; Krueger and Meskill 1992; Scurlock and Fox 1977). Therefore, brief descriptions are provided here and counts and proveniences are given in Appendix A.

\section{CERAMICS}

Goliad (Figure 6b) and other unglazed wares, made at the missions, make up the largest percentage of ceramics in all San Antonio mission sites. Burnished and lead-glazed earthenwares (Figure 6a) were made in Mexico and imported for mission use. A few sherds of Chinese-made porcelain (Figure 6i) are recovered in most mission excavations. Mexican made tin-glazed earthenwares, also called majolicas, comprise a relatively small portion of mission ceramic collections, but are important for dating purposes. Of the majolicas found during these excavations, three types are helpful in determining the date of occupation of the structure on the west wall.

A variety of Puebla Blue-on-white (Figure 6h) proposed by Ivey as San Antonio Blue-on-white (lvey and Fox 1982:42), has a double blue rim hand from which are suspended blue petals and flowers. The central design is generally a longlegged bird. The date range in San Antonio is ca. 1730 to 1750 .

San Elizario majolica (Figure 6j) is similar to San Antonio Blue-on-white, with the addition of a brown/black outline to a single blue rim band and with accents of the same color on the petals and bird. This type is found in San Antonio sites dating between 1755 and 1780 (Ivey and Fox 1982:43).

Tumacacori majolica (Figure 6f) has a pale blue background on which floral elements are painted in black, yellow, orange, green, and dark blue. Various dates have been suggested for this majolica type, from 1780 to 1860 (Barnes and May 1972), but it is clearly a turn-of-the-century or early nineteenth-century type in Texas.

Since all these types were found during the excavation of the structure and its immediate surroundings, this particular area was probably occupied throughout the Mission Concepción occupation of the site. The preponderance of unglazed Indian-made Goliad ware suggests this was an Indian residence.

San Augustine Blue-on-white majolica (Figure 6e) was found only in Unit 5, outside the mission wall. Decorated with blue patterns on a 
white background, this type dates to the mideighteenth century.

Whitewares, yellowwares, and stonewares were made first in England and Europe, then after the middle of the nineteenth century in the United States. Sites in San Antonio containing these sherds can be dated to the nineteenth and early twentieth centuries. Sherds of these types in these excavations are probably representative of the later occupations on this corner after evidence of the mission wall had totally disappeared.

\section{HOUSEHOLD ITEMS}

Glass container fragments from the site date from the eighteenth through the late twentieth century. Types ranging from Spanish wine bottles to recent beer and soft drink bottles are represented. Metal scrap recovered consists mainly of fragments of tin containers dating from the late nineteenth to the twentieth century.

A knife (Figure 6k) recovered from Trench $C$, within the structure built against the wall, is identical to others found in similar circumstances at Spanish colonial sites throughout the southwest (see Woodward 1953:187).

\section{PERSONAL ITEMS AND ACTIVITIES}

Two buttons were recovered from the general surface trash deposit east of the colonial structure. One was a cast metal button with a drilled shank, similar to many found at the other missions and San Antonio sites dating to the late eighteenth and early nineteenth century. The other button, represented by a small fragment, was made of bone. Such buttons are also found on sites of similar time periods.

Three marbles are present in this collection. Two glass marbles dating to the first half of the twentieth century (Jose Zapata, personal communication 1993) came from the test units outside the mission wall. The third, which was found outside the east wall of the colonial structure, was a clay marble of the type called a "commie," possibly homemade since it is outof-round and appears to have fingernail prints in the surface. These marbles are common in late nineteenth century sites and have been found to date as early as 1820 (Jose Zapata, personal communication 1993).

Two fragments of horse riding equipment were found outside the east wall of the colonial structure. One is an iron jingle or coscojo from a Spanish bridle bit (Simmons and Turley 1980:101). The other is a portion of a spur, the plate or barrilero from the end of the body of the spur (Simmons and Turley 1980:110).

\section{CONSTRUCTION}

As might be expected, since the area investigated had been occupied over such a long time, construction materials from various periods were present. Fragments of window and plate glass, wire nails, and a few cut nails were found in various locations. Fragments of typical colonial mortar were found in the vicinity of the structure. Several types of brick and tile were represented: twentieth century red/orange highfired tile, a few fragments of yellow brick, and two large fragments identifiable as missionperiod brick by their hand-made form and thickness $(3-3.5 \mathrm{~cm})$.

\section{CHERT}

Flakes and fragments of chert were found throughout the excavations, suggesting local manufacture of tools and projectile points during mission times. Two Mission or Guerrero projectile points (Figure $6 \mathrm{c}$ and $6 \mathrm{~d}$ ), one found around the colonial structure and one in Unit 5, are similar in size and craftsmanship to numerous others found at Mission Concepción and at other Spanish sites in Texas, as well as at Indian occupation sites of the same time period in Coahuila and South Texas (Ivey and Fox 1982:Figure 20; Turner and Hester 1993:216). 


\section{FAUNAL REMAINS}

A total of 2,736 bones and bone fragments was recovered during this project. Each specimen was identified to the species or genus level whenever possible, using CAR's comparative collection and standard texts on the identification of faunal remains from archaeological sites (Gilbert 1990; Hillson 1986; Olsen 1964, 1968).

\section{General Observations}

The vast majority of the bone was highly fragmented. In fact, 82.40 percent $(N=2,247)$ of the collection is unidentified vertebrate remains, i.e. it cannot be assigned with certainty even to the mammalian class (although virtually all is probably mammalian). Another 11.92 percent $(\mathrm{N}=325)$ could be identified only as fish, reptile (snake), bird, or mammal.

The highly fragmented condition of the bone resulted in a Number of Identified Specimens (NISP) of only 155 , or 5.67 percent of the collection. Fifteen species were identified (Table 2). A table with detailed proveniences of both identified and unidentified specimens is located in Appendix B.

Table 2. Faunal Species Identified

\begin{tabular}{|ll|}
\hline \multicolumn{1}{|c|}{ Scientific Name } & \multicolumn{1}{c|}{ Common Name } \\
\hline \hline Bos taurus & Cow \\
Caprid/Ovid' & Goat/Sheep \\
Sus scrofa & Domestic pig \\
Gallus gallus & Chicken \\
Equus caballos & Horse \\
Canis sp. & Dog (coyote, wolf) \\
Sylvilagus sp. & Cottontail rabbit \\
Procyon lotor & Raccoon \\
Lepus californicus & Jackrabbit \\
Didelphis marsupialis & Opossum \\
Sciurus niger & Fox squirrel \\
Odocoileus sp. & Deer \\
Neotoma albigula & White-throated wood rat \\
Oryzomys palustris & Rice rat \\
Lampropeltis getulus & King snake \\
\hline
\end{tabular}

'The difficulty of telling goat (Capra sp.) bone from sheep (Ovis sp.) bone is notorious and was not attempted for this highly fragmented collection. 
Very few butchering marks are found on this collection, probably because of the extent of fragmentation. Most of the identifiable bone from domestic food animals do, however, show signs of butchering. Butchering marks include chop marks (from hatchet- to cleaver-size tools), cut marks (from butcher knives and smaller), saw cuts (from both hand and machine saws), and impact fractures. Only nine saw-cut specimens are present, of which only two appear to be from a machine-powered saw. Both of these were found outside the midden area. The long bones and ribs of cattle, when in relatively large pieces, were particularly likely to show chopping marks. Some specimens of Bos taurus long bones had been hacked repeatedly by a large cleaver or hatchet.

\section{Estimating Relative Abundance}

In faunal studies, numerous ways to quantify the abundance of the represented species have been developed. The most commonly used are a count of the Number of Identified Specimens (NISP) and the derived-unit Minimum Number of Individuals (MNI). Serious problems are associated with using NISP to quantify the abundance of species. A large NISP of a given species could reflect a large number of animals of that species; however, it could also reflect that most or all of the skeleton of a single or a few individuals of that species are represented. Furthermore, a large NISP could mean that several identifiable fragments of a single bone have been counted (Grayson 1984:20-21). In addition to this, NISP has the potential to be heavily biased by differences between species in the effects of taphonomic processes, i.e., elements of some species may be more likely to be rendered unidentifiable by taphonomic processes, thus excluding them from consideration in the NISP (Lyman 1994:47).

Minimum Number of Individuals (MNI) is commonly used to avoid these problems. This unit is derived by dividing the identified specimens of a given species into left and right elements and using a count of the most abundant of these elements as the minimum number of animals of that species represented by the identified bone. Size and age of the animals are sometimes also taken into consideration (for instance, the presence of a left proximal tibia which has an unsealed epiphysis and a right proximal tibia with a sealed epiphysis would indicate an MNI of two, one adult and one juvenile). Care must be taken to prevent counting, say, a single left tibia twice by counting both distal and proximal ends.

Grayson (1984:29-49) points out that MNI also has grave problems, showing that the MNI of a species in a faunal collection can be greatly altered depending on how the faunal collection is aggregated by the analyst. That is, a large difference in MNI numbers can be produced depending on how the specimens from a site are grouped: the entire site taken as a unit, or divided by excavation unit, arbitrary level, natural level, or any other division (Grayson $1984: 37$ ). The only way to avoid this problem is to insure that the degree to which a faunal collection is divided reflects the actual way in which faunal material was deposited in the site. This clearly cannot be done with any certainty in many, if not most, sites. It remains a fundamental problem for the use of MNI in measuring abundance. In addition to this problem, MNI tends to over-emphasize the value of small animals (Reitz and Scarry 1985:17) and the importance of rare species (P. Ducos, cited by Grayson 1984:50).

After studying the relationship between NISP and $\mathrm{MNI}$ in numerous faunal collections, Grayson concludes that NISP and MNI are related to each other in a linear fashion. Given this, NISP is the preferred method for determining relative abundance, since NISP is not plagued by the problems associated with differential aggregation (Grayson 1984:68). However, this still does not solve the problems that NISP does have. Grayson suggests that these problems cannot be solved in a single site, but that comparison of several sites in a region is possible using NISP and/or MNI as ordinal measures of the abundance of species. Both 
NISP and MNI have been calculated for this collection, and are listed in Table 3. MNI was calculated using all of Trench $\mathrm{C}$ and its extension as a group, Trenches $E$ and $F$ as separate groups, Units $1-5$ as a single group, and Unit 11 as a single group.
Both NISP and MNI indicate the importance of cattle among species represented in this collection (Table 3), though NISP stresses this importance much more than MNI does. Taken together, domestic food animals (cattle, goat/sheep, pig, and chicken) constitute 80.00 percent of the NISP but only 40.73 percent of the MNI.

Table 3. NISP and MNI of Identified Bones

\begin{tabular}{|c|c|c|c|c|}
\hline & NISP & $\begin{array}{c}\% \text { of Total } \\
\text { NISP }\end{array}$ & MNI & $\begin{array}{c}\text { \% of Total } \\
\text { MNI }\end{array}$ \\
\hline Bos taurus & 86 & 55.48 & $\overline{4}$ & 14.81 \\
\hline Caprid/Ovid & 20 & 12.90 & 3 & 11.11 \\
\hline Sus scrofa & 17 & 10.97 & 3 & 11.11 \\
\hline Gallus gallus & 1 & 0.65 & 1 & 3.70 \\
\hline Equus caballos & 1 & 0.65 & 1 & 3.70 \\
\hline Canis sp. & 3 & 1.94 & 2 & 7.41 \\
\hline Sylvilagus sp. & 7 & 4.52 & 2 & 7.41 \\
\hline Procyon lotor & 3 & 1.94 & 2 & 7.41 \\
\hline Lepus californicus & 1 & 0.65 & 1 & 3.70 \\
\hline Didelphis marsupialis & 2 & 1.29 & 1 & 3.70 \\
\hline Sciurus niger & 6 & 3.87 & 2 & 7.41 \\
\hline Odocoileus sp. & 3 & 1.94 & 1 & 3.70 \\
\hline Neotoma albigula & 2 & 1.29 & 1 & 3.70 \\
\hline Oryzomys palustris & 2 & 1.29 & 2 & 7.41 \\
\hline Lampropeltis getulus & 1 & 0.65 & 1 & 3.70 \\
\hline Totals & 155 & & 27 & \\
\hline
\end{tabular}


The rank order of the identified species in this collection is given in Table 4. Comparison of the relative abundance of the less common species reveals that in a small collection such as this, use of MNI is of questionable merit as an indicator of relative abundance, except, perhaps, as a very general indicator. Based on MNI, dogs, rabbits, squirrels, and rice rats are of approximately equal abundance, while chickens, horses, deer, opossum, jackrabbits, and wood rats seem less common (Table 4). In fact, this grouping is almost useless, considering the small range of MNI across species. It seems clear that the combination of a comparatively small sample and a very low percentage of identifiable bone makes the usefulness of MNI questionable at best. NISP, though still suffering from the problems discussed above, seems to be a more useful measure of relative abundance in small collections.

\section{Colonial Versus Mixed Levels}

The dateable artifacts recovered during this project suggest that the trash midden encountered in Trench $\mathrm{C}$, the Trench $\mathrm{C}$ extension, and Trench $\mathrm{F}$ is a Colonial-period feature, with no sign of mixture with later periods. Altogether 2,345 ( 85.71 percent) bones and bone fragments were from these two trenches. Only 391 specimens were recovered in the other units, which contained both colonial artifacts and artifacts dated to later periods.

Table 4. Rank Order of Identified Species by NISP and MNI

\begin{tabular}{|lcc|}
\hline Species Identified & $\begin{array}{c}\text { Rank Order } \\
\text { by NISP }\end{array}$ & $\begin{array}{c}\text { Rank Order } \\
\text { by MNI }\end{array}$ \\
\hline Bos taurus & 1 & 1 \\
Caprid/Ovid & 2 & 2 \\
Sus scrofa & 3 & 2 \\
Gallus domesticus & 8 & 4 \\
Equus caballos & 8 & 4 \\
Canis sp. & 6 & 3 \\
Sylvilagus sp. & 4 & 3 \\
Procyon lotor & 6 & 3 \\
Lepus californicus & 8 & 4 \\
Didelphis marsupialis & 7 & 4 \\
Sciurus niger & 5 & 3 \\
Odocoileus sp. & 6 & 4 \\
Neotoma albigula & 7 & 4 \\
Oryzomys palustris & 7 & 3 \\
Lampropeltis getulus & 8 & 4 \\
\hline
\end{tabular}


Table 5 presents a comparison of Colonial-versus mixed-period NISP for this collection; however, it should be noted that this comparison is of questionable value, due to the small sample size of the bone from the mixed-period units. Reitz and Scarry (1985:21) note that a small sample size (i.e. less than 1,400 bone fragments) has been shown to poorly represent both number of species and relative abundance of species. Table 5 should be viewed with this in mind.
The identified bone from the mixed-period units contains elements from eight different species, while the identified bone from the Colonialperiod units contain elements from 11 species. While 85.93 percent of the NISP from the colonial units is from domestic food animals, only 52.84 percent of the bone from the mixedperiod units is from domestic food animals. Thus the Colonial-period bone shows more diversity in number of species, as well as a heavy concentration of bone from domestic food animals.

Table 5. Comparison of Colonial- Versus Mixed-period NISP

\begin{tabular}{|l|c|c|c|c|}
\hline & $\begin{array}{c}\text { Trenches } \\
\text { C and F }\end{array}$ & $\begin{array}{c}\text { \% of } \\
\text { Total }\end{array}$ & $\begin{array}{c}\text { Other } \\
\text { Units }\end{array}$ & $\begin{array}{c}\text { \% of } \\
\text { Total }\end{array}$ \\
\hline \hline Bos taurus & $\mathbf{7 4}$ & 57.81 & $\mathbf{1 2}$ & 44.44 \\
\hline Caprid/Ovid & $\mathbf{1 9}$ & 14.84 & $\mathbf{1}$ & 3.70 \\
\hline Sus scrofa & $\mathbf{1 6}$ & 12.50 & $\mathbf{1}$ & 3.70 \\
\hline Gallus gallus & $\mathbf{1}$ & 0.78 & $\mathbf{0}$ & 0.00 \\
\hline Equus caballos & $\mathbf{0}$ & 0.00 & $\mathbf{1}$ & 3.70 \\
\hline Canis sp. & $\mathbf{0}$ & 0.00 & $\mathbf{3}$ & 11.11 \\
\hline Sylvilagus sp. & $\mathbf{3}$ & 2.34 & $\mathbf{4}$ & 14.81 \\
\hline Procyon lotor & $\mathbf{0}$ & 0.00 & $\mathbf{3}$ & 11.11 \\
\hline Lepus californicus & $\mathbf{1}$ & $\mathbf{0 . 7 8}$ & $\mathbf{0}$ & 0.00 \\
\hline Didelphis marsupialis & $\mathbf{2}$ & 1.56 & $\mathbf{0}$ & 0.00 \\
\hline Sciuris niger & $\mathbf{6}$ & 4.69 & $\mathbf{0}$ & 0.00 \\
\hline Odocoileus virginianus & $\mathbf{3}$ & 2.34 & $\mathbf{0}$ & 0.00 \\
\hline Neotoma albigula & $\mathbf{0}$ & 0.00 & $\mathbf{2}$ & 7.41 \\
\hline Oryzomys palustris & $\mathbf{2}$ & 1.56 & $\mathbf{0}$ & $\mathbf{0}$ \\
\hline Lampropeltis getulus & $\mathbf{1}$ & 0.78 & $\mathbf{0}$ & $\mathbf{0 . 0 0}$ \\
\hline Totals & $\mathbf{1 2 8}$ & & $\mathbf{2 7}$ & \\
\hline
\end{tabular}


Comparison With Mission San José Bone Collections

Recent excavations (Hard et al. 1994) at Mission San José y San Miguel de Aguayo (41BX3) offer a possibility of comparison of bone from this collection with bone from colonial levels of another Spanish-mission site. In spring 1993, CAR excavated a series of test units outside the south wall and inside the compound of Mission San José, which lies approximately three miles down the San Antonio River from Mission Concepción. The purpose of these tests was to determine if proposed construction of a visitors' center and redrainage of the compound would impact valuable cultural deposits (Hard et al., 1994:vi).

Six hand-dug excavation units and 83 shovel tests were dug. The latter were spaced at $50-\mathrm{m}$ intervals in a grid across the entire compound (Hard et al., 1994:36-38). A total of 7,066 bones was recovered during these excavations. Of these 1,736 were from unit/levels containing artifacts dated exclusively to the Colonial period. Table 6 is a comparison of the NISP of the San José bone with that from colonial units (Trench $\mathrm{C}$, its extension, and Trench $\mathrm{F}$ ) recovered during this project. Table 6 reveals a distinct difference in relative abundance of species in these two collections. Only 39.00 percent of the identifiable Colonial-period Mission San José bone is from domestic food animals. Even if the 15 Crotalus atrox bone are removed from this collection (a procedure justified by the fact that 14 of these are from a single, articulated individual, which constitutes a perfect example of some of the problems with using NISP to define relative abundance), the total percentage of identified bone which is from domestic food animals is only 45.88 percent. This difference can be largely explained by the presence of so much deer and rabbit, which together constitute 29.00 percent of the San José NISP (34.12 percent if $C$. atrox is not included), but only 5.46 percent of the Mission Concepción NISP.

\section{Discussion}

The highly fragmented nature of the bone recovered during this project is not unusual in mission-period sites (Hard et al. 1994:68; Meissner 1993). The reasons for this are not entirely understood. Activities which could lead to this kind of fragmentation include the smashing of long bones to extract marrow, the boiling of bones to extract tallow, the burning of bones (as trash or for fuel), and trampling. Of these, little evidence for the extensive burning of bone is found, only 118 (4.33 percent) of the bone showed evidence of burning. This indicates that the little burning of bone which occurred was incidental. Any or all of the other activities which might cause bone fragmentation could have been responsible for the condition of this collection.

The species identified in this collection are typical for historic sites in San Antonio. Only the low numbers of snakes and rats are unusual. This is especially true of Sigmodon hispidus, the hispid cotton rat, one of the most common species identified in faunal remains from Bexar County. This species constituted 28.12 percent of the identified specimens recovered during the archaeological excavations at Mission Concepción in 1971-72 (Scurlock and Fox 1977:150). None was identified in this collection and only four specimens from other rat species ( $N$. albigula and $O$. palustris) were identified.

The virtual absence of chicken (Gallus gallus) in this collection is consistent with a pattern seen in colonial sites in Bexar County. In three previous faunal analyses, no chicken was recovered from unmixed colonial levels (Davidson and Clark 1977:135; Hard et al. 1994:72; Scurlock and Fox 1977:Table I-2). Chicken was apparently not a significant part of the diet in the Colonial period. 
Table 6. NISP Comparison of Mission San José and Mission Concepción Faunal Remains

\begin{tabular}{|l|c|c|c|c|}
\hline \multicolumn{1}{|c|}{ Species Identified } & $\begin{array}{c}\text { Mission } \\
\text { Concepción }\end{array}$ & $\begin{array}{c}\text { \% of } \\
\text { Total }\end{array}$ & $\begin{array}{c}\text { Mission } \\
\text { San José }\end{array}$ & $\begin{array}{c}\text { \% of } \\
\text { Total }\end{array}$ \\
\hline Bos taurus & 74 & 57.81 & 27 & 7.00 \\
\hline Caprid/Ovid & 19 & 14.84 & 8 & 8.00 \\
\hline Sus scrofa & 16 & 12.50 & 4 & 4.00 \\
\hline Gallus gallus & 1 & 0.78 & 0 & 0.00 \\
\hline Equus caballos & 0 & 0.00 & 2 & 2.00 \\
\hline Canis sp. & 0 & 0.00 & 6 & 6.00 \\
\hline Sylvilagus sp. & 3 & 2.34 & 9 & 9.00 \\
\hline Procyon lotor & 0 & 0.00 & 0 & 0.00 \\
\hline Lepus californicus & 1 & 0.78 & 5 & 5.00 \\
\hline Didelphis marsupialis & 2 & 1.56 & 0 & 0.00 \\
\hline Sciuris niger & 6 & 4.69 & 1 & 1.00 \\
\hline Odocoileus virginianus & 3 & 2.34 & 15 & 15.00 \\
\hline Neotoma albigula & 0 & 0.00 & 0 & 0.00 \\
\hline Oryzomys palustris & 2 & 1.56 & 2 & 2.00 \\
\hline Lampropeltis getulus & 128 & 0.78 & 4 & 4.00 \\
\hline Crotalus atrox & 0 & 0.00 & 15 & 15.00 \\
\hline Sigmodon hispidus & 0.00 & 1 & 1.00 \\
\hline Nerodia sp. & 0 & & 1 & \\
\hline & 0 & 000 & \\
\hline
\end{tabular}

Wild species commonly used for food, such as raccoon ( $P$. lotor), opossum (D. marsupialis). rabbits (Sylvilagus sp. and L. californicus'), and deer (Odocoileus sp.), are present in this collection, but are unusually sparse in number of elements identified, as shown in Table 3 (see also Davidson and Clark 1978:136; Hard et al. 1994:71,73-74; Meissner 1993). The emphasis on domestic meat animals in this collection is made even stronger when the number of bones which have been identified as being "cow-sized" is considered (see Appendix B). A total of 210 bone fragments was identified as "cow-sized," and the vast majority, if not all, of these were probably Bos taurus. Clearly the people depositing the faunal materials of this collection were eating a great deal of beef.

\section{Conclusions}

Recovered artifacts indicate the midden areas excavated in Trenches $\mathrm{C}$ and $\mathrm{F}$ date to the Colonial period. The faunal remains from these middens show a heavy emphasis on domesticated food animals, especially cattle. Unlike other 
species inventories from previous excavations of Colonial-period deposits in the Spanish missions of San Antonio, including Mission Concepción, wild animals are a minor constituent of this collection.

The glaring absence of $S$. hispidus and the sparse remains of other rats, especially in the Colonialperiod trenches, rate some consideration. The smaller rats, including $S$. hispidus and $O$. palustris, may have been part of the diet of the Indians who entered the mission, but would have been starvation food for those heavily influenced by European culture. The ubiquitous representation of these species in Colonial-period faunal remains is, therefore, probably the result of scavenging of food in human occupation sites by the rats themselves. Their failure to appear in significant numbers in the collection under study here suggests three possibilities:

1) the colonial midden was strictly kitchen refuse, i.e. not a general trash midden where any stray dead animals might be thrown (the fact that only three specimens of species which were probably not used as food were identified is evidence in support of this);

2) the trash in this midden was immediately buried, thus discouraging scavenging by rodents;

3) bone boiled to extract tallow had so little food value left that it did not attract scavengers.

Any or all these possibilities may have been factors in the absence of rats in the collection.

In conclusion, the relative proportions of the faunal material from this project, especially from the Colonial period, is unusual for the period. There is less use of wild food animals and fewer rodents than is usually seen in Colonial-period faunal collections. However, the small sample size and highly fragmented condition of the vertebrate remains from this project make it necessary to consider these conclusions with some caution.

\section{ARTIFACT DISCUSSION}

The artifacts recovered from Trench $\mathrm{C}$, Trench $\mathrm{F}$, and the Trench C-extension (Appendix A) are much the same as those found in other Spanish colonial area excavations at Mission Concepción and at the other San Antonio missions, including Mission San Antonio de Valero (now called the Alamo). In other words, they are typical of the time period beginning in 1731 and ending in 1793 to 1820 , when the missions essentially ceased to exist as missions and therefore no longer received supplies from Mexico through the established supply system.

The range of majolica dates suggests that the structure built against the wall probably existed through most of the mission period and may have been occupied during much of that time. It may even have continued in existence in some form into the early nineteenth century after the property was acquired by Ygnacio Chávez.

\section{CONCLUSIONS AND RECOMMENDATIONS}

The results of these investigations allow the following answers to the questions posed in the research design.

1) The remains of the west wall of the mission quadrangle do indeed extend beyond the Theo-Mission Road intersection.

2) The wall foundation appears to be in good condition except in a few places where conflicting later house foundations have disturbed it, and near the 
northwest corner where it is disturbed by a buried utility line.

3) The northwest corner of the mission wall is buried under the present route of Mission Road.

4) What appears to be a mission-period Indian house is built against the west wall in the area of the investigations. This indicates that others are present along the wall toward the south. These remains will not be in any way impacted by the relocation of the road.

We recommend that any further disturbance of the mission compound at any point inside the west wall be proceeded by archaeological investigations planned in such a way as to thoroughly uncover and examine an area at least $10 \mathrm{~m}$ wide along the inside of the wall. We also recommend that a brief project be undertaken to locate the line of the north mission wall so the location of the northwest corner of the compound may be projected. This should be done after the new road alignment has been constructed and the old road surface removed.

\section{EPILOGUE}

By spring 1990 construction on the new route of Mission Road had essentially been completed, the previous road had been totally removed and the area resurfaced with grass. Few people driving past Mission Concepción today would suspect that Mission Road once ran through the quadrangle. 


\section{REFERENCES CITED}

Barnes, M. R., and R. V. May

1972 Mexican Majolica in Northern New Spain. Pacific Coast Archaeological Society Occasional Papers 2. Costa Mesa, California.

Campbell, T. N., and T. J. Campbell

1985 Indian Groups Associated With Spanish Missions of the San Antonio Missions National Historical Park. Special Report, No. 16, Center for Archaeological Research, The University of Texas at San Antonio.

Cisneros, $\mathrm{J}$.

1980 San Antonio Missions National Historical Park, San Antonio, Texas, Statement for Management. U.S. Department of the Interior. National Park Service.

Corner, W.

1890 San Antonio de Bexar: A Guide and History. Bainbridge and Corner, San Antonio.

Council of Texas Archeologists (CTA)

1981 Guidelines for Cultural Resource Management Reports. Council of Texas Archeologists Newsletter 5(2).

Davidson, B., and J. W. Clark

1978 Faunal Analysis. In Mission San José y San Miguel de Aguayo Archaeological Investigations, December 1974, by J. W. Clark, pp. 135-143. Texas Historical Commission, Austin.

Fox, A. A.

1988 Archaeological Excavations at Mission Concepción, Fall 1986. Archaeological Survey Report, No. 172, Center for Archaeological Research, The University of Texas at San Antonio.
1989 Monitoring of Utility Trenches at Mission Concepción, San Antonio, Texas, 1988. Archaeological Survey Report, No. 180, Center for Archaeological Research, The University of Texas at San Antonio.

Gilbert, B. M.

1990 Mammalian Osteology. Missouri Archaeological Society, Columbia.

Grayson, D. K.

1984 Quantitative Zooarchaeology. Academic Press, New York.

Habig, M. A.

1968 The Alamo Chain of Missions, $A$ History of San Antonio's Five Old Missions. Franciscan Herald Press, Chicago.

Hard, R. J., A. A. Fox, K. J. Gross, B. A. Meissner, G. Mendez, C. L. Tennis, and J. Zapata

1994 Excavations at San José and San Miguel de Aguayo, San Antonio, Texas. Archaeological Survey Report, No. 218, Center for Archaeological Research, The University of Texas at San Antonio.

Hillson, S.

1986 Teeth. Cambridge University Press, Cambridge.

Ivey, J. E., and A. A. Fox

1982 Archaeological Investigations at Mission Concepción and Mission Parkway. Archaeological Survey Report, No. 114, manuscript on file at the Center for Archaeological Research, The University of Texas at San Antonio. 
Krueger, M., and F. Meskill

1992 Test Excavations at Mission Concepción Courtyard, San Antonio, Bexar County, Texas. Archaeological Survey Report, No. 214, Center for Archaeological Research, The University of Texas at San Antonio.

Lyman, R. L.

1994 Quantitative Units and Terminology in Zooarchaeology. American Antiquity 59(1):36-71.

Ivey, J. E., and M. B. Thurber

1984 The Missions of San Antonio, A Historic Structures Report and Administrative History. Part I: The Spanish Colonial Missions, edited by Tom Ireland. National Park Service, Southwest Cultural Resources Center. Santa Fe, New Mexico.

Labadie, J. H.

1989 Archaeological and Historical Investigations for the Mission Road Realignment Project, San Antonio, Texas. Archaeological Survey Report, No. 173, Center for Archaeological Research, The University of Texas at San Antonio.

Meissner, B. A.

1993 Faunal Remains Recovered During San Juan Drainage Project. In ArchaeologicalTesting and Monitoring in Connection with a Drainage Project at Mission San Juan Capistrano, San Antonio, Bexar County, Texas, edited by A. A. Fox, pp. 27-35. Archaeological Survey Report, No. 217, Center for Archaeological Research, The University of Texas at San Antonio.
Olsen, S. J.

1964 Mammal Remains from Archaeological Sites Part I: Southeastern and Southwestern United States. Peabody Museum, Cambridge.

1968 Fish, Amphibian, and Reptile Remains from Archaeological Sites Part I: Southeastern and Southwestern United States. Peabody Museum, Cambridge.

Reitz, E. J., and C. M. Scarry

1985 Reconstructing Historic Subsistence With An Example from SixteenthCentury Spanish Florida. Special Publication Series No. 3, Society for Historical Archaeology, Ann Arbor.

Schuetz, M. K.

1968 The History and Archaeology of Mission San Juan Capistrano, San Antonio, Texas, Volume I. Report 10 , State Building Commission Archaeological Program, Austin.

Scurlock, D., and D. E. Fox

1977 An Archaeological Investigation of Mission Concepción, San Antonio, Texas. Report 28, Office of the State Archeologist, Austin.

Simmons, M., and F. Turley

1980 Southwestern Colonial Ironwork, the Spanish Blacksmithing Tradition from Texas to California. Museum of New Mexico Press, Santa Fe.

Taylor, F. B., R. B. Hailey, and D. L. Richmond

1966 Soil Survey of Bexar County, Texas. United States Department of Agriculture, Soil Conservation Service, in cooperation with the Texas Agricultural Experiment Station, Series 1962(12). 
Turner, E. S., and T. R. Hester

1993 A Field Guide to the Stone Artifacts of Texas Indians. 2nd edition. Gulf Publishing, Houston.

Woodward, A.

1953 Spanish Metals. In The Sobaipuri Indians of the Upper San Pedro River Valley, edited by C. C. Di Peso. The Amerind Foundation, Report 6. Dragoon, Arizona. 
APPENDIX A: ARTIFACT COUNTS AND PROVENIENCES

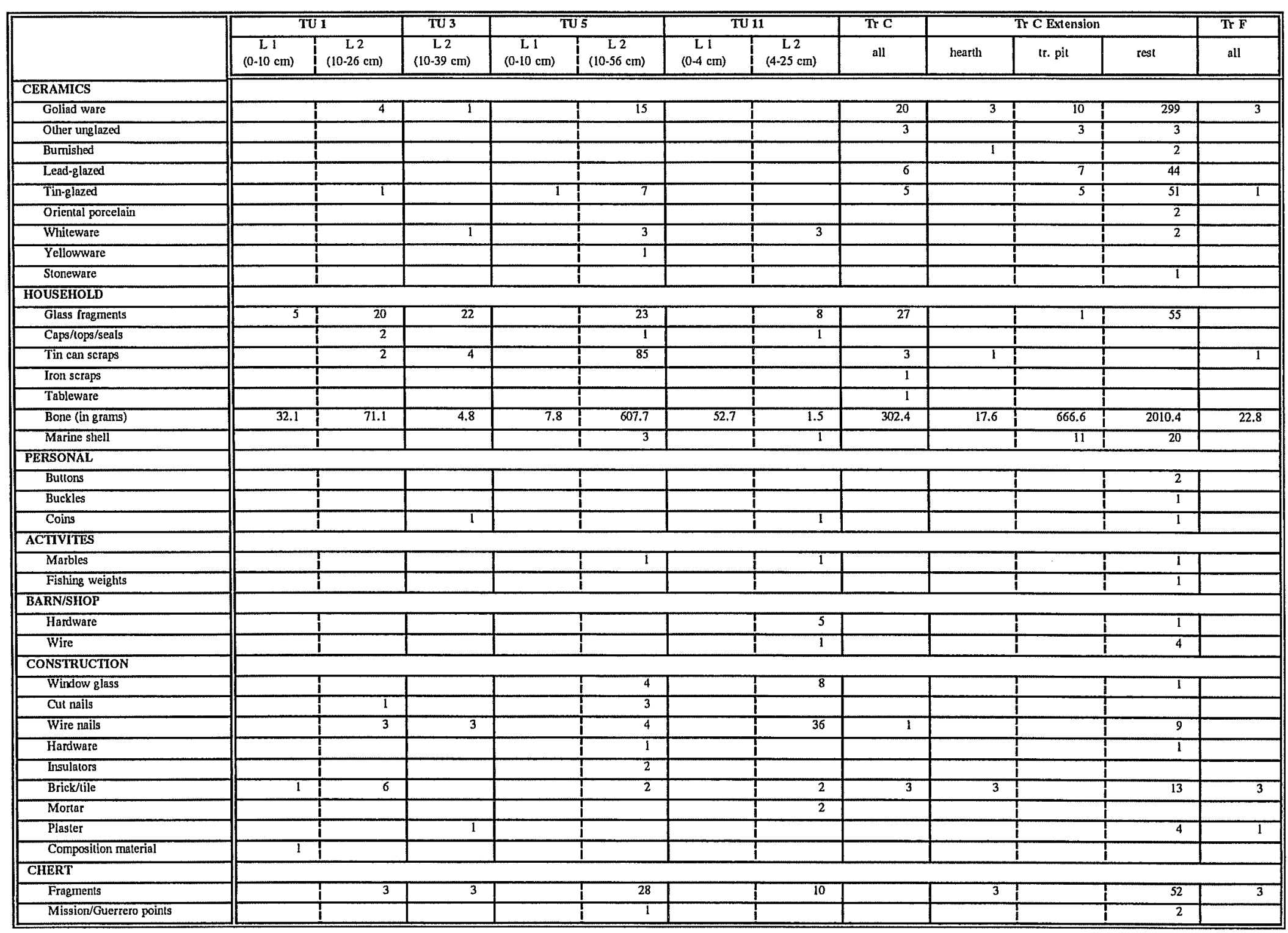




\section{APPENDIX B: FAUNAL REMAINS DATA}

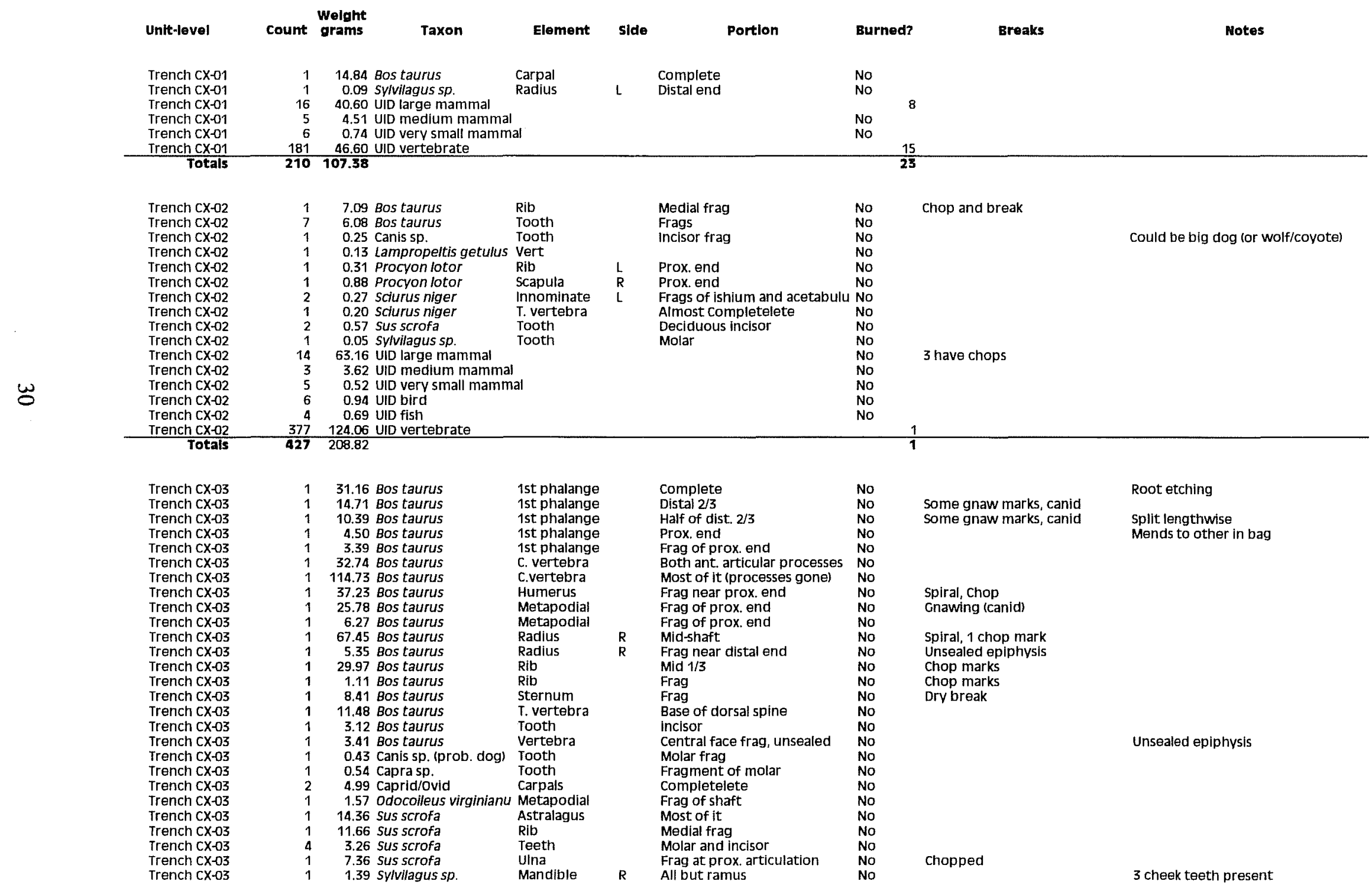




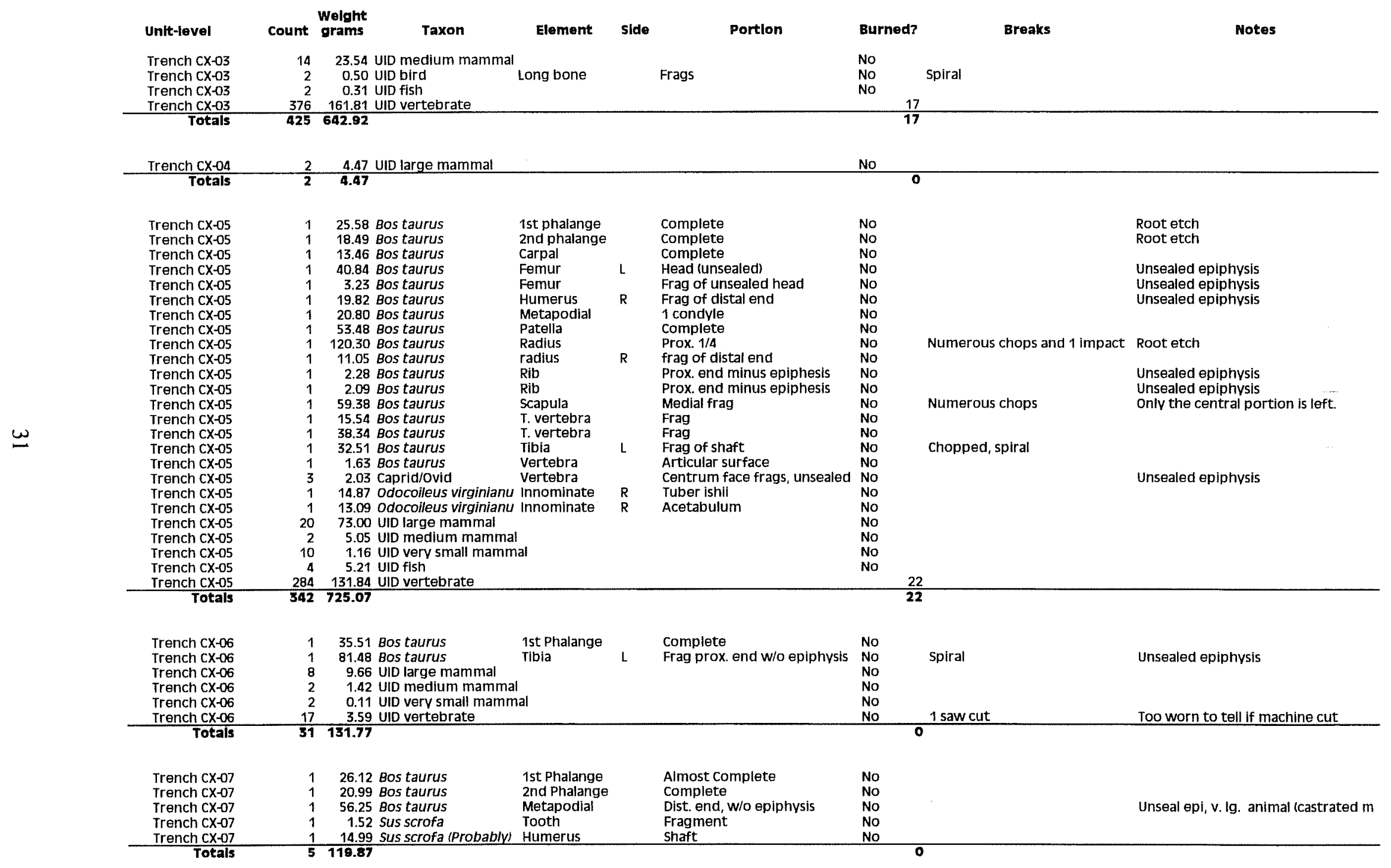




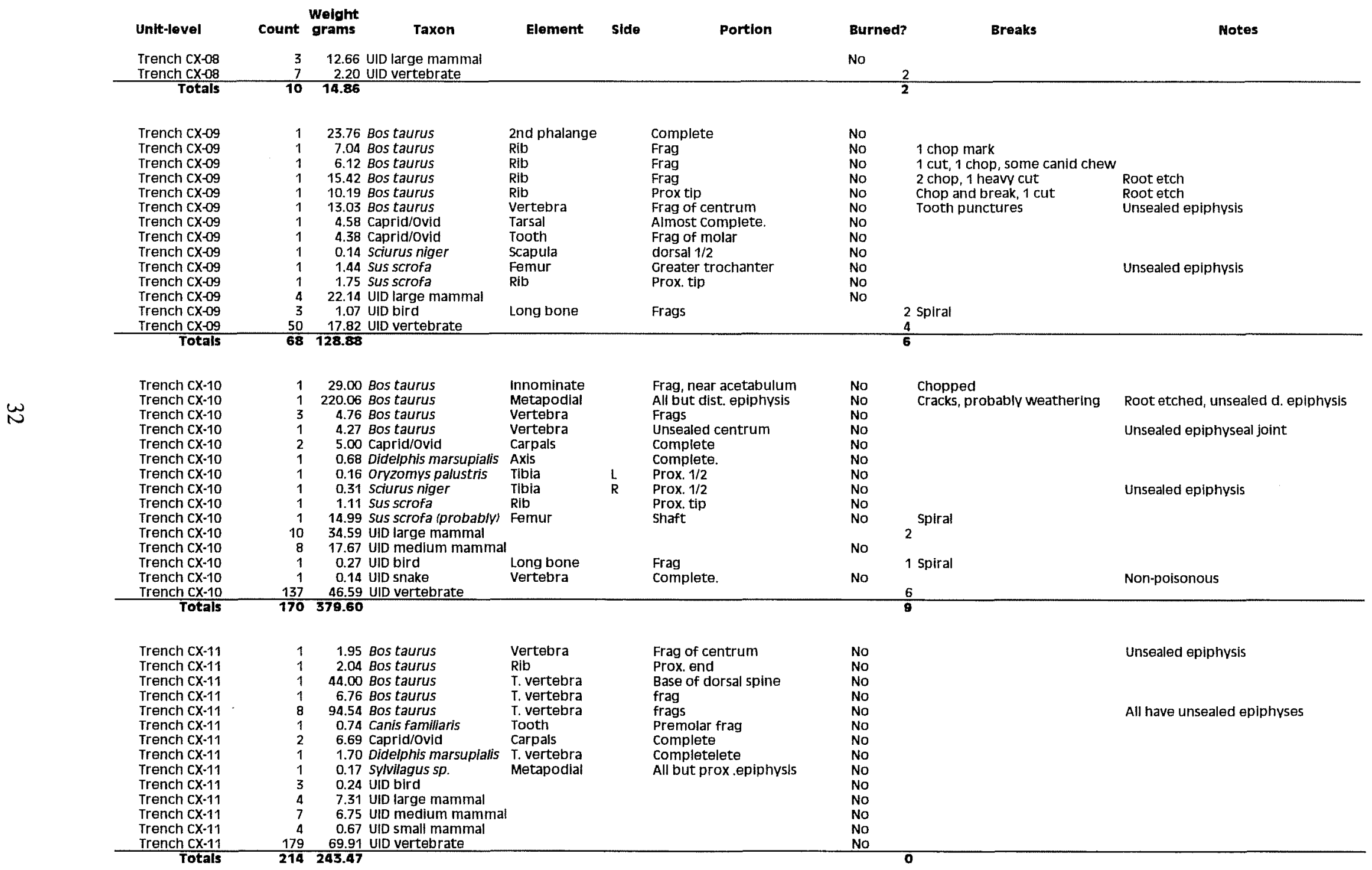




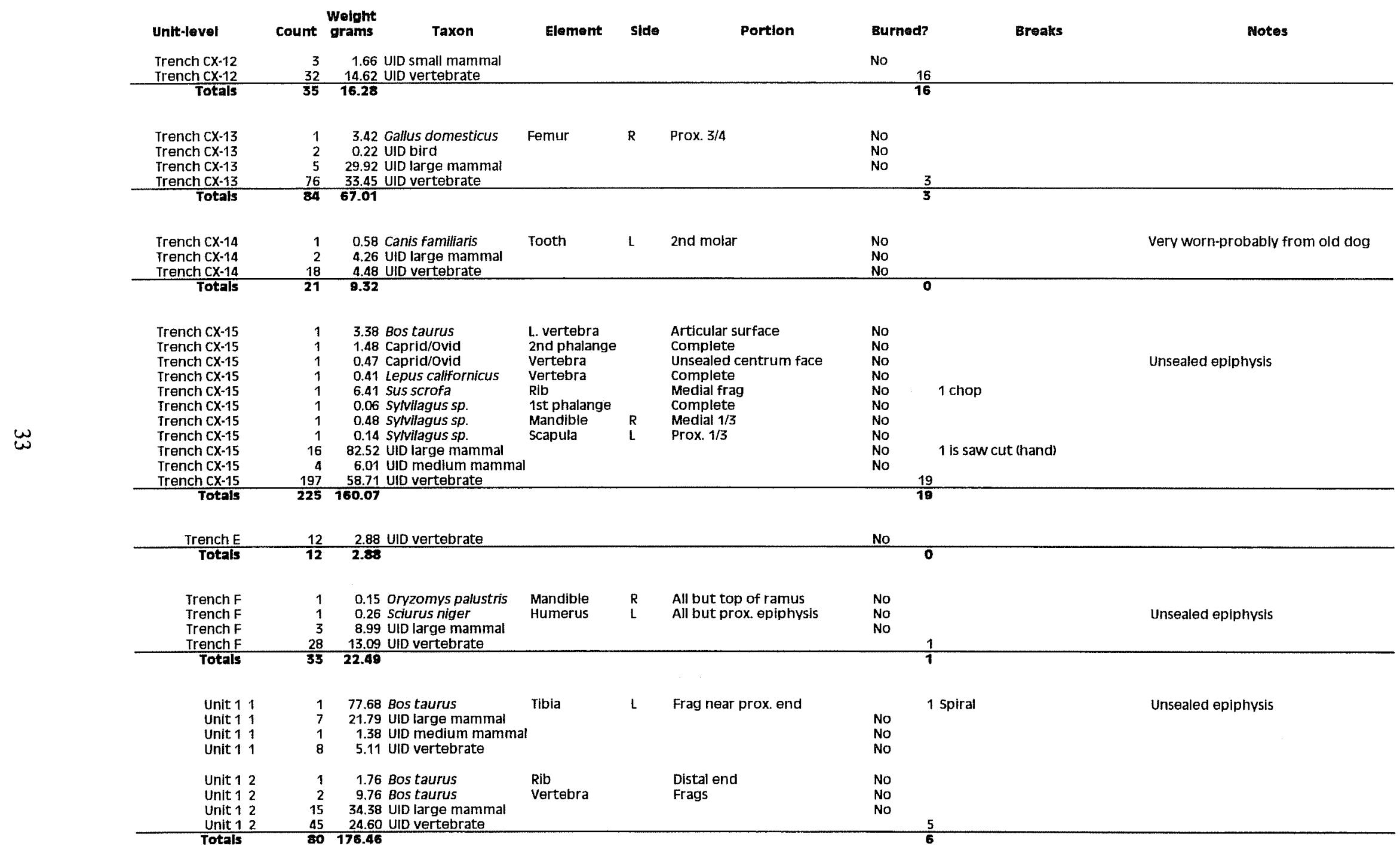




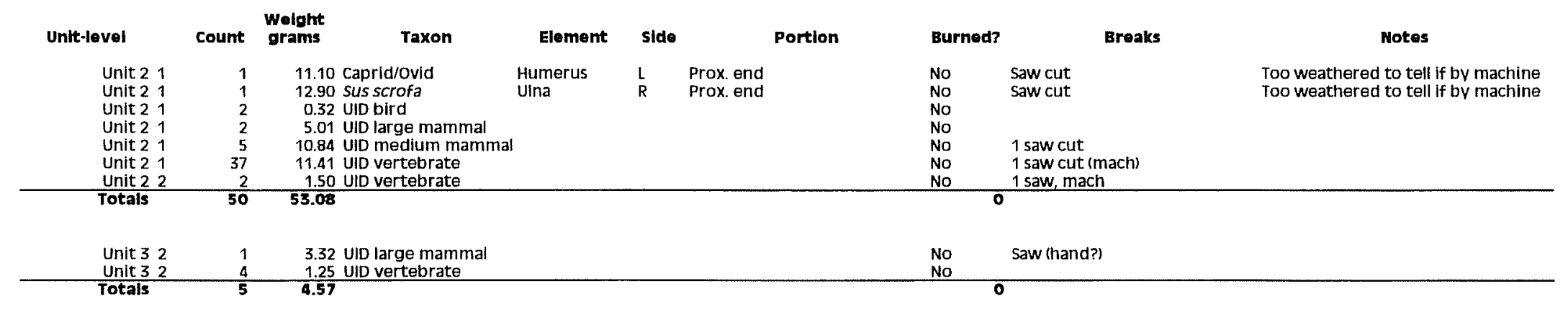

\begin{tabular}{|c|c|c|c|c|c|c|c|}
\hline 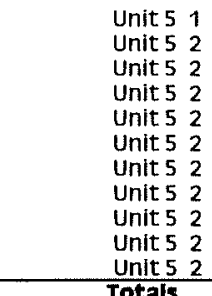 & $\begin{array}{r}2 \\
1 \\
1 \\
4 \\
1 \\
1 \\
1 \\
1 \\
40 \\
1 \\
191 \\
200\end{array}$ & $\begin{array}{l}7.65 \text { Bos taurus } \\
\text { 145.24 Bos taurus } \\
3.30 \text { Bos taurus } \\
0.41 \text { Bos taurus } \\
\text { 4.20 Equus caballos } \\
0.41 \text { Equotoma albigula } \\
0.33 \text { Neotoma albigula } \\
\text { 1.33 Procoron lotor } \\
\text { 163.64 UID large mammal } \\
\text { 0.35 UID very small mamm } \\
79.94 \text { UID vertebrate } \\
\end{array}$ & $\begin{array}{l}\text { Rib } \\
\text { Metapodial } \\
\text { sternum } \\
\text { Vertebra } \\
\text { Rib } \\
\text { Remur } \\
\text { Mandible } \\
\text { Mandible } \\
\text { lal } \\
\end{array}$ & $\begin{array}{l}\mathrm{L} \\
R \\
R\end{array}$ & $\begin{array}{l}\text { Medial frags } \\
\text { Most of prox. } 1 / 2 \\
\text { Medial frag, } \\
\text { Frags of centrum face, unseal } \\
\text { Medial frag } \\
\text { Prox. 2/3 } \\
\text { All but ramus } \\
\text { Medial 1/3 }\end{array}$ & $\begin{array}{l}\text { No } \\
\text { No } \\
\text { No } \\
\text { No } \\
\text { No } \\
\text { No } \\
\text { No } \\
\text { No }\end{array}$ & $\begin{array}{l}\text { Unsealed epiphysis } \\
\text { Badly weather, but may be chopped }\end{array}$ \\
\hline & & 406.80 & & & & & \\
\hline $\begin{array}{c}\text { Total Trencher } \\
\text { Total other } \\
\text { Overall total }\end{array}$ & $\frac{2302}{\frac{391}{2693}}$ & $\begin{array}{r}2982.28 \\
643.79 \\
3626.07\end{array}$ & & & Totalburned bone & & $\sqrt{172}$ \\
\hline
\end{tabular}

